\title{
Land-Use and Land-Cover Change Detection in a North-Eastern Wetland Ecosystem of Bangladesh Using Remote Sensing and GIS Techniques
}

\author{
Shwarnali Bhattacharjee ${ }^{1} \cdot$ Md Tariqul Islam $^{1}\left[\right.$ Dohammad Ehsanul Kabir ${ }^{2} \cdot$ Md Muhib Kabir $^{3}$
}

Received: 2 January 2021 / Revised: 17 May 2021 / Accepted: 22 May 2021 / Published online: 4 June 2021

(c) The Author(s) 2021

\begin{abstract}
Lakshmibaur-Nalair Haor, a freshwater wetland ecosystem is situated in the north-eastern region of Bangladesh. This place hosts the second largest freshwater swamp forest in Bangladesh. Containing rich biodiversity, this unique area experiences significant landscape changes. This study examines land-use and land-cover (LULC) changes between 1989 and 2019 in the Lakshmibaur-Nalair Haor area by operating Landsat multispectral imageries through remote sensing (RS) and geographic information system (GIS) techniques. The changing status of the haor was analyzed by initiating normalized difference vegetation index (NDVI) and modified normalized difference water index (MNDWI). The unsupervised classification technique was implemented to classify these images into five major classes (vegetation, cropland, bare soil, shallow water, and deep water bodies) using threshold values of NDVI and MNDWI. After accuracy assessment, the post-classification comparison method was performed to evaluate the change detection. This study demonstrates that this valuable area lost $\sim 2208.6$ ha (37.54\%) of the deep water body and 489.6 ha (8.34\%) of vegetation over the last 3 decades. However, it has gained about 1729 ha (29.39\%) of cropland, 2673 ha (45.44\%) of shallow water and 1124 ha (28\%) of bare soil. Such changes indicate significant human interventions such as expansion of croplands with increased population pressure. Gradual change of deep water into shallow water over time is enabling local community to expand agricultural lands and activities during the dry season. This study's findings are useful in understanding and tracking changes in wetlands in Bangladesh and other similar settings.
\end{abstract}

Keywords LULC $\cdot$ NDVI $\cdot$ MNDWI $\cdot$ Haors $\cdot$ Bangladesh

Md Tariqul Islam

islam-gee@sust.edu

Shwarnali Bhattacharjee

bhattacharjee.shwarnali@gmail.com

Mohammad Ehsanul Kabir

m.e.kabir@lancaster.ac.uk

Md Muhib Kabir

mdkab1@morgan.edu

1 Department of Geography and Environment, Shahjalal University of Science and Technology (SUST), Sylhet 3114, Bangladesh

2 Lancaster Environment Centre, Lancaster University, Lancaster LA1 4YQ, UK

3 Department of Transportation and Urban Infrastructure Studies, Morgan State University, 1700 E. Cold Spring Lane, Baltimore, MD 21251, USA

\section{Introduction}

Wetlands play crucial role in global biodiversity and provide essential support to many species and people's livelihood across the world. These lands are among the most productive ecosystems which not only delivers larger degree of ecosystem services but also accommodating many endangered species in aquatic and terrestrial environment (Mitsch and Gosselink 1993; Ricaurte et al. 2017). Wetlands often seen as transitional lands between terrestrial and aquatic ecosystems, especially where shallow water covers the land, or the water table is generally at or near the land surface. Such wetlands are classified into seven landscape units, namely, estuarine, open coast, floodplains, freshwater marshes, lakes, peatlands and swamp forest (Cowardin and Golet 1995; Dugan 1990). Since 1990 , about $64 \%$ of the wetlands have lost natural features worldwide. Over the last 40 years, almost $76 \%$ of freshwater animals and plants have also disappeared (UNEP 
2015). Both natural and human-induced land-cover changes in the wetland areas impact the environment and society due to their inevitable interactions (Houghton 1994).

In Bangladesh, wetlands cover about 80,000 sq. km area, which is nearly half of the area of the entire country including streams, rivers, lakes, ponds, marshes, haors, baors, ${ }^{1}$ beels, ${ }^{2}$ and jheels ${ }^{3}$ (Islam et al. 2018; Tatu and Anderson 2017). Among these, haors are large bowl-shaped depressions between the natural levees of rivers, which receives surface runoff water every year during monsoon and become huge water body for half of a year (Nishat 1993). Haors dry up after monsoon and become vast green lands during winter. These haors are found in the Haor basin, situated in the north-eastern part of Bangladesh (Rasheed 2008). In Bangladesh, total haor region consists of 373 haors covering about 859,000 ha lands, which cover $10 \%$ of the country's total wetland area (BHWDB 2012). About 50\% population of the entire country are primarily dependent on wetland resources for their livelihood (Islam 2010). Nearly $70 \%$ of consumed animal protein comes from freshwater fishes and 6-8\% of revenue comes from the country's marsh areas only (Kanan 2016).

Globally, tracking spatio-temporal variations in the wetlands along with adjacent uplands is essential to understand possible human interventions along with many natural changes (Ozesmi and Bauer 2002). Assessing LULC changes across the wetland ecosystems are commonly used by disciplines such as environmental management, land-use planning, resource management and climate studies (Chamling and Bera 2020). LULC changes detection commonly demonstrates spatio-temporal patterns of changes in wetlands, which can contribute to sustainable usage and management of wetland resources (Rahimi et al. 2020). To examine when, where or how LULC changes occurs, the change detection models usually examine empirically captured data about physical characteristics of an area with certain period of time to see any historical patterns of changes. These also help future projection of changes which are likely to occur. These data can be obtained more reliably through the uses of RS process (Alam et al. 2020).

Satellite remote sensing is cost-efficient method being widely used by contemporary researchers to gather spatial and temporal information on wetlands (Guo et al. 2017;

\footnotetext{
${ }_{1}$ Ox-bow lakes are known as baors in southwestern Bangladesh, formed due to the separation of a meander from the main river (Rasheed 2008).

${ }^{2}$ Lake like wetlands but filled with static water locally known as 'Beel' are commonly found in the haor areas of Bangladesh (Akter 2011).

${ }^{3}$ Freshwater marshes are usually referred to jheels_-often the term is used to determine permanent water bodies of different sizes (Rasheed 2008).
}

Mahdavi et al. 2018). RS and GIS techniques are highly functional to develop LULC mapping to obtain spatial analysis (Barakat et al. 2019). These have the potentials to provide precise information associated with LULC changes (Alqurashi and Kumar 2013). Assessment of LULC changes in wetlands using RS continuously helps to detect and resist different environmental threats, which are prerequisite for conservation of natural habitats of wetlands (SánchezEspinosa and Schröder 2019). Thus, space-born satellite data have gained immense acceptability and being widely used in LULC change studies across the world (Ahmed 2011; Elagouz et al. 2020; Hassan 2017; Kaliraj et al. 2017; Kumar and Ghosh 2012; Rawat and Kumar 2015; and Sewnet 2016). Moreover, Landsat satellite imageries, amongst other satellite products, have become more popular in the scientific community due to broader coverage, free availability and acceptable resolution (Mao et al. 2020). Studies that have used such products for the mapping and monitoring of wetlands include Haque and Basak (2017) who involved satellite images such as Landsat multispectral scanner system (MSS), Landsat thematic mapper (TM) and Landsat enhanced thematic mapper (ETM) to determine spatio-temporal land-cover changes in Tanguar Haor, located in northern Sylhet region in Bangladesh. Cong et al. (2019) used satellite imageries of Landsat MSS, TM and operational land imager-thermal infrared sensor (OLITIRS) to analyze the dynamic changes in the wetland landscape pattern of the Yellow River Delta in China from 1976 to 2016.

Despite haor's influential role in its surrounding terrestrial environment, only a few prominent haors in Bangladesh have been studied so far. Though the LakshmibaurNalair Haor could draw attention for being the second largest freshwater swamp forest in Bangladesh (Deshwara and Eagle 2017), no research work has yet been conducted involving this haor. Therefore, this study is principally comprised of the Lakshmibaur-Nalair Haor, situated in the north-eastern haor basin of Bangladesh. The aim of this study is to detect spatio-temporal LULC changes between 1989 and 2019 in Lakshmibaur-Nalair Haor. The main objective of the study is to apply NDVI and MNDWI indices to assess the nature, rate and magnitude of changes in this haor. Using satellite imageries of Landsat TM and Landsat OLI-TIRS through RS and GIS techniques, this study examines an unexplored wetland area in the country. The findings of this study will help to identify the past and present land scenarios in this haor area, which can potentially guide policy makers and managers with scientific evidence for improved haor management.

Published in partnership with CECCR at King Abdulaziz University 


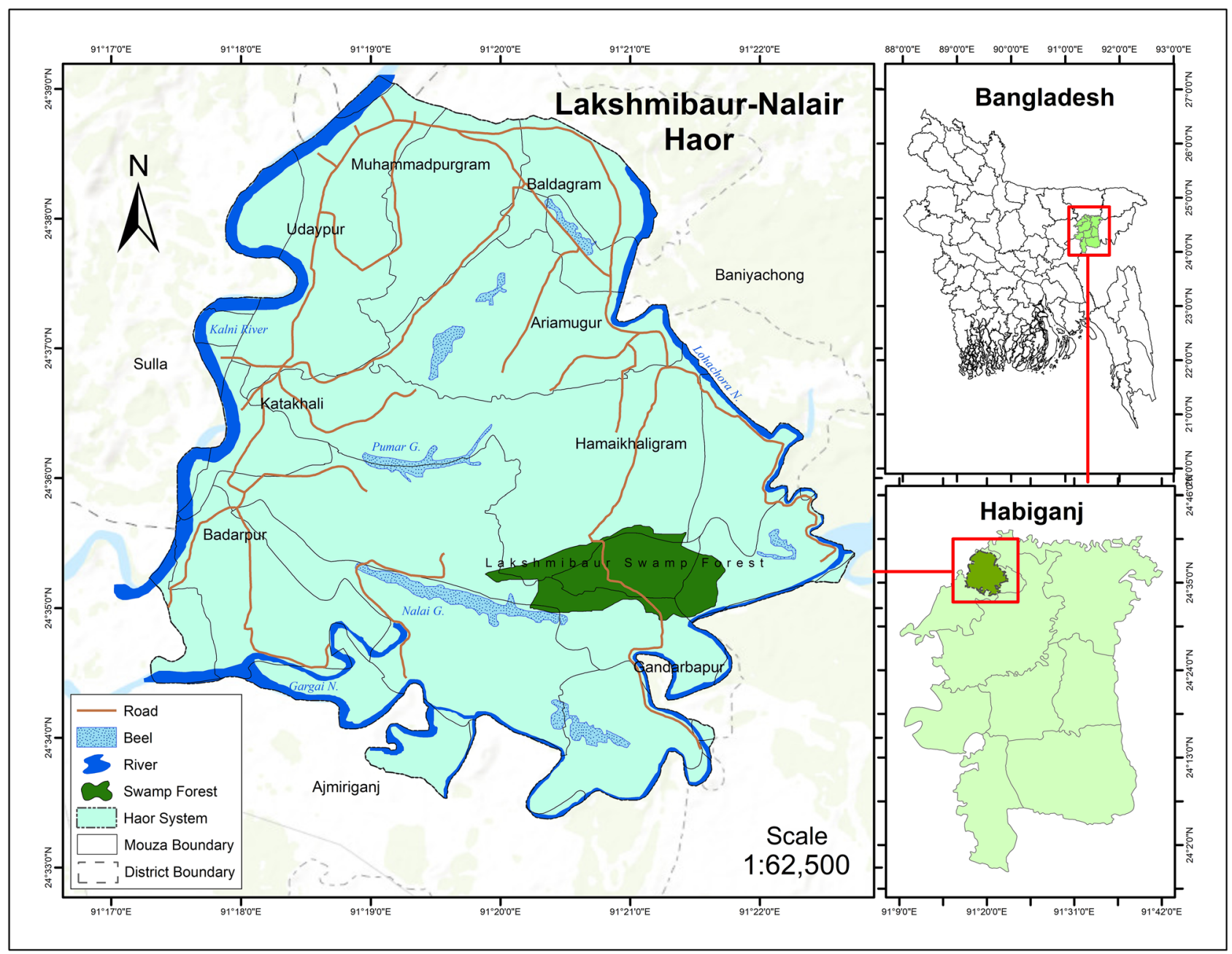

Fig. 1 Geographical location of Lakshmibaur-Nalair Haor in Habiganj district of Bangladesh. Base map source: Department of Bangladesh Haor and Wetlands Development (2016)

\section{Study Area}

Lakshmibaur-Nalair Haor is located between $24^{\circ} 37^{\prime} 9.01^{\prime \prime} \mathrm{N}$ and $24^{\circ} 36^{\prime} 27.29^{\prime \prime} \mathrm{N}$ latitudes and between $91^{\circ} 17^{\prime} 54.47^{\prime \prime} \mathrm{E}$ and $91^{\circ} 21^{\prime} 31.14^{\prime \prime} \mathrm{E}$ longitudes, which is in the northwestern side of Habiganj district in Bangladesh (see Fig. 1). Within the entire extent of Lakshmibaur-Nalair Haor, there are two sub-districts (upazilas) within Habiganj district, namely, Ajmiriganj and Baniyachong. This haor covers about 5365 ha (BHWDB 2012) area, adjacent to Kalni River in the west and Kushiyara River both in the south and the east. This haor area accommodates 17 villages where the villagers are largely dependent on locally available natural resources. This study area includes multiple Beels; Nalair G. and Pumar G. are the two largest beels located within Lakshmibaur-Nalair Haor. Lakshmibaur freshwater swamp forest is also a unique ecosystem in the study area, located in the southeastern part of this haor. About 520 acre forest lands are submerged under seven-eight feet of water during monsoon, starting from May to October every year (Deshwara and Eagle 2017). Locally, this swamp forest is known as "Khorotir Jungle".

In the context of physiography of Bangladesh (Brammer 2012), Lakshmibaur-Nalair Haor is part of the Surma-Kushiyara floodplain, which is further divided into two sub-units: Sylhet basin and Eastern Surma-Kushiyara floodplain. Sylhet Basin covers larger portion of this haor, whereas a smaller part is covered by Eastern SurmaKushiyara floodplain (see Fig. 2). Geological characteristics include alluvial silt and clay, marsh clay and peat surface sediments long deposited in the Holocene epoch of Lakshmibaur-Nalair Haor (see Fig. 2) (Alam et al. 1990). Alluvial silt and clay surface sediments deposited in the northern region while marsh clay and peat sediment deposited in the southern part of the study area. According to the soil classification in Bangladesh (Brammer 


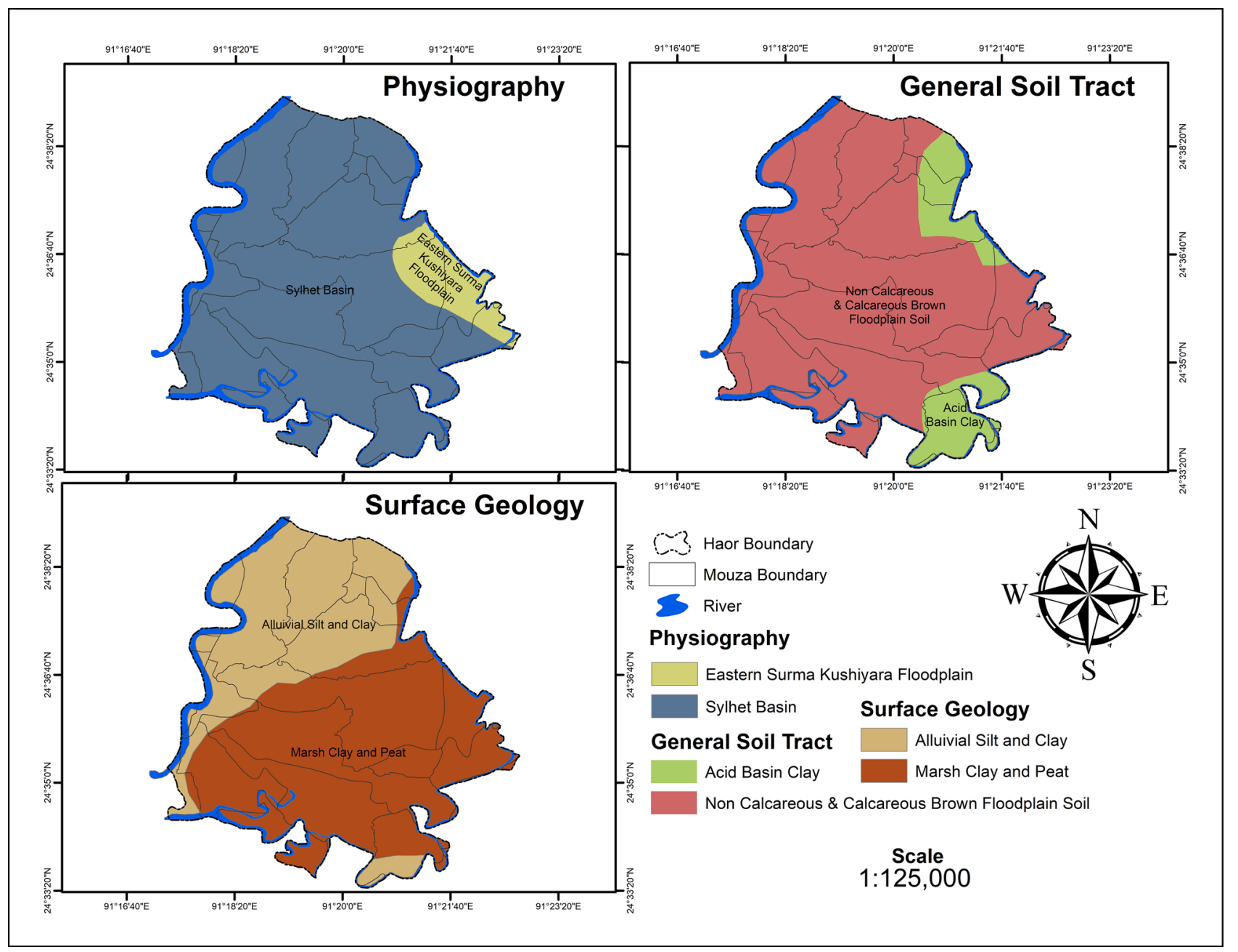

Fig. 2 Physiography, general soil tract and surface geology of Lakshmibaur-Nalair Haor

1996), the entire haor consists of two units: acid basin clay and non-calcareous calcareous brown floodplain soil (see Fig. 2).

The study area has a tropical monsoon climatic condition, which is identified by the bi-annual inversion of air movement. Air flows from the north-east between December and March, then it flows from the south-west between June and September (Ali 2014). Monsoon season appears from June to October and supplies over $80 \%$ of the annual rainfall. Air temperature usually fluctuates between $26^{\circ} \mathrm{C}$ and $31{ }^{\circ} \mathrm{C}$ during pre-monsoon season (March to May), between $28{ }^{\circ} \mathrm{C}$ and $31{ }^{\circ} \mathrm{C}$ during rainy season and between $26^{\circ} \mathrm{C}$ and $27^{\circ} \mathrm{C}$ during dry season (Bennett et al. 1995). A map of temporal RGB Landsat satellite imageries of the Lakshmibaur-Nalair Haor dated 1989, 1999, 2009 and 2019 is shown in Fig. 3 with truecolor composite 321 for Landsat TM and 432 for Landsat OLI-TIRS.

\section{Materials and Methods}

\subsection{Data Sources}

This study has exploited two different sensors of Landsat Level-1 satellite products, where processing levels of the both include terrain precision correction. Landsat-5 TM satellite imageries of 1989, 1999 and 2009 and Landsat-8 OLI-TIRS satellite image of 2019, were obtained from the USGS (United States Geological Survey) official website. Landsat-5 TM imageries comprise seven spectral bands of which the spatial resolution for bands $1-5$ and 7 is $30 \mathrm{~m}$ and band 6 comes with $120 \mathrm{~m}$ spatial resolution (resampled to $30 \mathrm{~m}$ pixels). Landsat 8 OLI-TIRS include eleven spectral bands and $30 \mathrm{~m}$ spatial resolution for bands $1-8$. Spatial resolution for bands 10 and 11 are $100 \mathrm{~m}$ each (resampled to $30 \mathrm{~m}$ ). Landsat 8 has 16-bit radiometric 


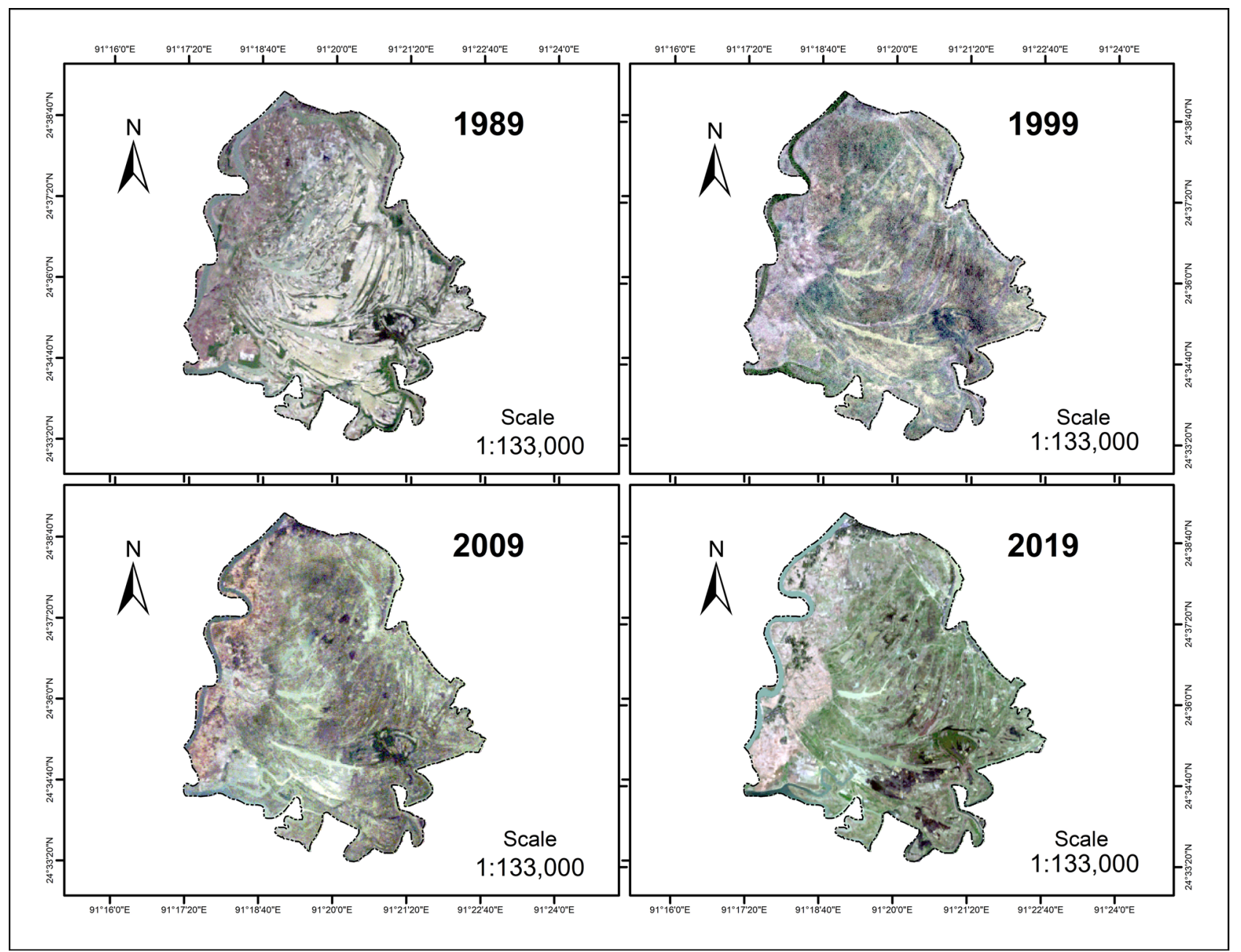

Fig. 3 Temporal RGB Landsat satellite imageries of Lakshmibaur-Nalair Haor

Table 1 Properties of acquired satellite images

\begin{tabular}{llllll}
\hline Satellite ID & Sensor name & Path/raw & Acquisition date & $\begin{array}{l}\text { Spatial resolu- } \\
\text { tion }(\mathrm{m})\end{array}$ & Quality \\
\hline Landsat 5 & TM & $137 / 43$ & $04-01-1989$ & 30 & 9 \\
Landsat 5 & TM & $137 / 43$ & $16-01-1999$ & 30 & 7 \\
Landsat 5 & TM & $137 / 43$ & $11-01-2009$ & 30 & 9 \\
Landsat 8 & OLI/TIRS & $137 / 43$ & $07-01-2019$ & 30 & 9 \\
\hline
\end{tabular}

resolution while Landsat 5 has 8-bit radiometric resolution. Landsat 8 has a greater spectral resolution (more spectral bands) than Landsat 5. Both Landsat 5 and Landsat 8 have the 16 day temporal resolution. We obtained all of these satellite images from the same season of the year, which is basically dry time in January to reduce the influence of cloud coverage and seasonal changes on the classification procedure that could otherwise distress the eminence of the resulting imageries. In the haor area, winter is the main season for rice cultivation, particularly Boro (a local variety) rice (Alam et al. 1970). The month January has been chosen for analyzing this study also because from December to January is the sowing time for Boro rice farming (Kalpoma et al. 2019). Four satellite images were selected with 10 years of the time interval starting from 1989 to 2019 to analyze 30 years' LULC changes within the haor (see Table 1). 


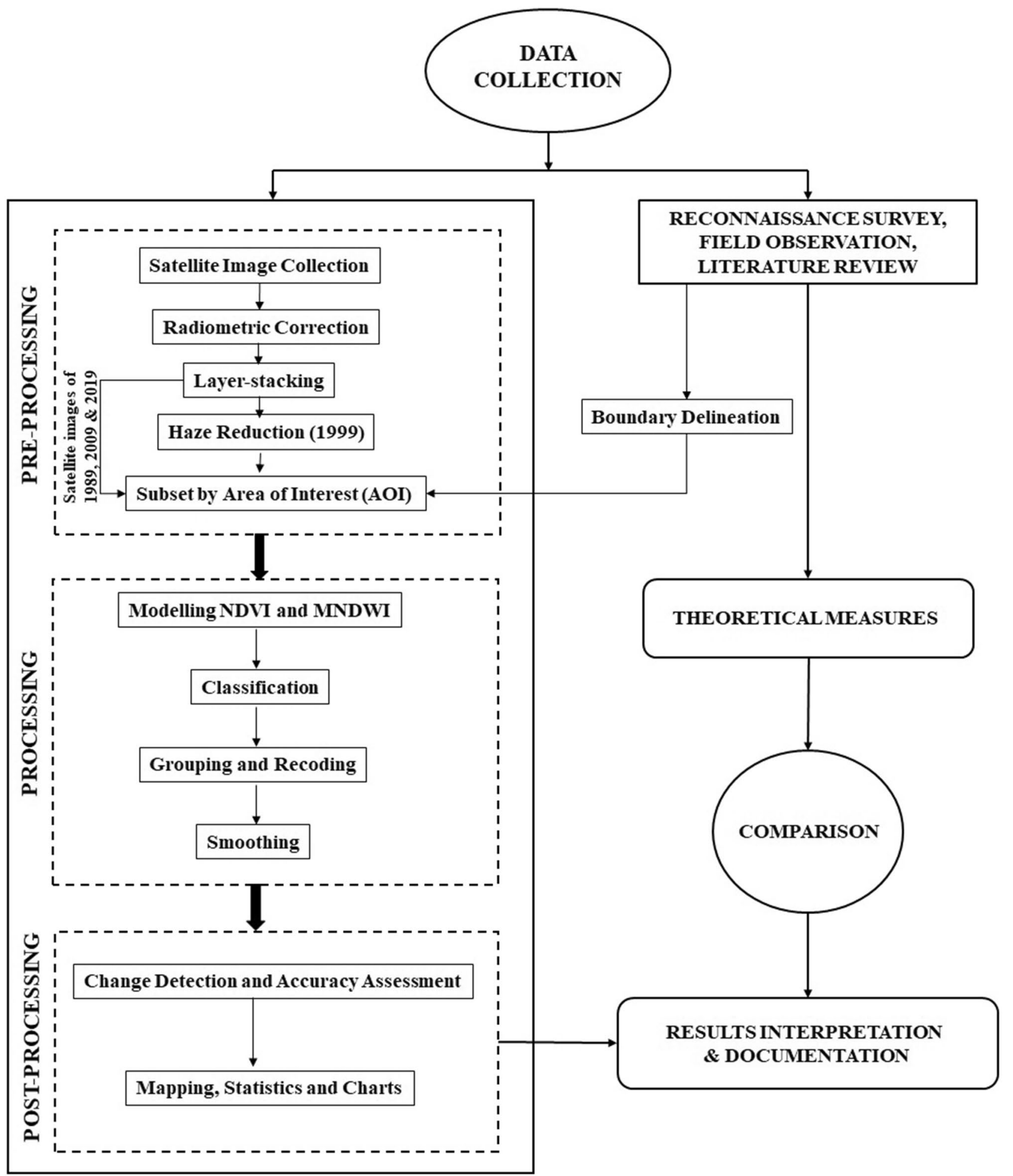

Fig. 4 Methodology flowchart 


\subsection{Base Map Collection}

This study's base maps include Lakshmibaur-Nalair Haor boundary map, union ${ }^{4}$ map, upazila map, mouza ${ }^{5}$ map and Topographical Sheet (No. 78 p/6). Lakshmibaur-Nalair Haor boundary map was collected from the Master Plan of Haor Area developed by Bangladesh Government's Wetland and Haor Development Board through digitization. Mouza, union, and upazila shapefiles were accumulated from an open-source of GIS inventory named Geo Planning for Advanced Development in Bangladesh (GPADBD).

\subsection{Processing and Analysis of Satellite Image}

Image pre-processing, processing and post-processing are three categories of the present study's procedure, as displayed in Fig. 4. RS and GIS techniques using few software namely, ArcGIS 10.6, ERDAS imagine 2014 and ENVI 5.3 were applied to accomplish the methods of this research.

\subsubsection{Image Pre-processing}

After acquiring Landsat-5 TM (1989, 1999, and 2009) and Landsat OLI-TIRS (2019) images of the study site, conversion of Digital Number (DN) values to Top of Atmosphere (ToA) reflectance was conducted following standard procedures provided by the USGS (2018). Geometrically and radiometrically corrected satellite images of years 1989, 1999, 2009 and 2019 of the study site were imported to the ERDAS Imagine software after the discrete spectral bands were stacked into a layer. Using ERDAS Imagine haze reduction tool, haze reduction was implicated on the satellite image of 1999 to reduce visual haze and improve the image's visualization. Figure 5 shows the pre-haze reduction and post-haze reduction satellite images of 1999. All satellite images were geo-rectified during analysis and projected to GCS WGS 1984 UTM Zone 43 N (datum) to confirm uniformity between datasets. Additionally, subsetting of images was prepared to extricate the area of interest (AOI), applying a vector shapefile of each dataset's haor boundary.

\subsubsection{Image Processing}

In this study, NDVI and MNDWI indices have been analyzed respectably to calculate and visualize the vegetation cover and water cover feature of Lakshmibaur-Nalair Haor.

3.3.2.1 NDVI and MNDWI NDVI is a widely used, wellknown index to determine and anticipate the biomass

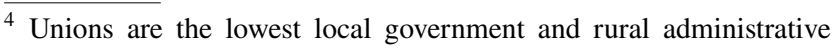
units in Bangladesh (Khan 2008).

5 A Mouza is a specific land area with settlements that is used as a revenue collection unit (Islam 2003).
}

and the greenness in a specific region (Alphan and Derse 2013; Tan et al. 2012). MNDWI is a more suitable index to enhance and extract information from the water surface area dominated by build-up land and mixed with vegetation (Singh et al. 2015; Xu 2006). NDVI and MNDWI are enumerated employing Eqs. (1) and (2) as illustrated below, respectively.

$\mathrm{NDVI}=\frac{(\mathrm{NIR}-\mathrm{RED})}{(\mathrm{NIR}+\mathrm{RED})}$

MNDWI $=\frac{(\text { GREEN }- \text { MIR })}{(\text { GREEN }+ \text { MIR })}$

According to USGS, satellite images of Landsat 5 and Landsat 8 have different spectral bands for calculating NDVI and MNDWI values. Landsat-5 (TM) has assigned spectral bands 2, 3, 4, and 5 for green, red, near infrared (NIR) and middle infrared (MIR), respectively. Whereas, Landsat- 8 (OLI-TIRS) has allotted spectral bands 3, 4, 5 and 6 for green, red, near infrared (NIR) and middle infrared (MIR), respectively (USGS 2017).

The NDVI and MNDWI values range from -1 to +1 . The accurate NDVI and MNDWI values for classification are attained by examining various threshold values and visually scrutinizing the tested images of the satellite (Jawak and Luis 2013). Authors synthesized the most common values of NDVI and MNDWI and the corresponding classes (illustrated in Table 2) from Mozumder et al. (2014), Gandhi et al. (2015), Haque and Basak (2017) and Eid et al. (2020). ERDAS Imagine spatial model maker tool was used to get the NDVI and MNDWI values from four Landsat satellite images. Figures 6 and 7 display the temporal NDVI and MNDWI images of Landsat satellite for the years 1989, 1999, 2009 and 2019 respectively, prepared in ArcGIS software by utilizing NDVI and MNDWI values.

3.3.2.2 Unsupervised Classification This study applied the NDVI and MNDWI indices for demonstrating the scenario of the haor area. NDVI and MNDWI values were classified using the unsupervised classification method. Then, using the threshold values shown in Table 3, we reclassified the NDVI values into four classes: vegetation, cropland, bare soil and no-vegetation. Similarly, the MNDWI values are classified into three categories: deep water, shallow water and non-water surface. We used the model maker tool of the ERDAS Imagine software for such reclassification.

\subsubsection{Image Post-processing}

3.3.3.1 Accuracy Assessment The accuracy assessment is a verifying process conducted to validate the generated image classifications' authenticity. Accuracy of classifications must 


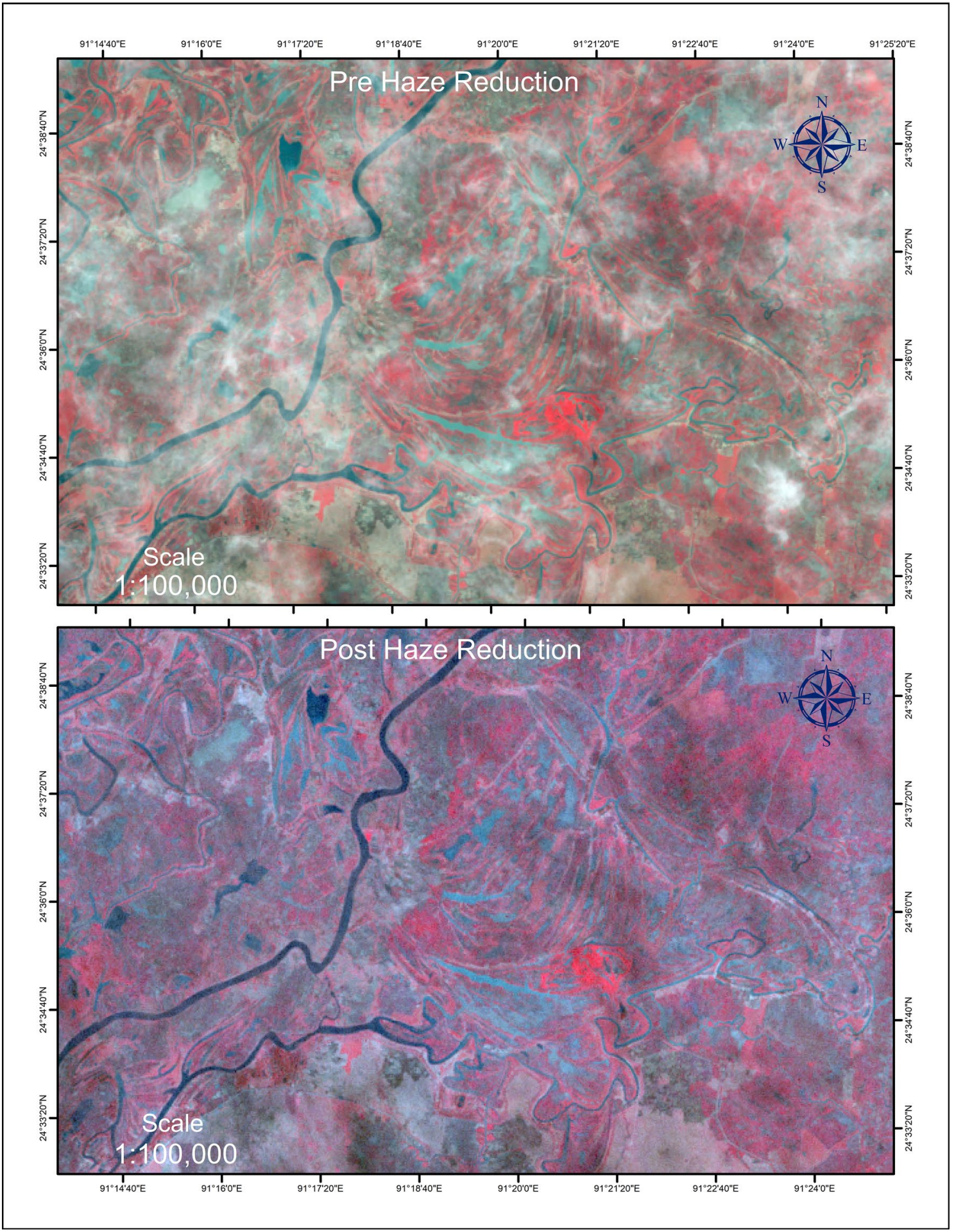

Fig. 5 Pre and post haze reduction of the 1999 satellite image

be done through ground-truthing in the study site. Thus, 50 ground control points (GCPs) collected from the field were applied on the NDVI and MNDWI classified images of the year 2019 in a random manner. One of the most frequently used-Kappa accuracy assessment technique was chosen to assess the accuracy of these images. Accuracy assessments of 1989, 1999 and 2009 images were not possible due to the vivid google earth images' unavailability. The overall accuracy of NDVI and MNDWI classified images of 2019 were $86 \%$ and $90 \%$, with overall Kappa statistics of $80.38 \%$ and 
Table 2 NDVI and MNDWI values, and corresponding classes

\begin{tabular}{|c|c|c|c|}
\hline NDVI intervals & Classes & MNDWI intervals & Classes \\
\hline 0.1 or less & Barren areas of rock, sand, or snow & -1 to 0 & Non-water surface \\
\hline 0.2 to 0.3 & Grass and shrubland & 0 to 0.3 & $\begin{array}{l}\text { Shallow water (semi } \\
\text { inundated land filled } \\
\text { with marshy vegeta- } \\
\text { tion) }\end{array}$ \\
\hline 0.6 to 0.8 & Tropical and temperate rainforests & 0.3 to 1 & $\begin{array}{l}\text { Deep water (river, per- } \\
\text { manent open water, } \\
\text { perennial lakes and } \\
\text { reservoirs) }\end{array}$ \\
\hline Close to zero & Bare soil & & \\
\hline Negative values & Water bodies & & \\
\hline
\end{tabular}

$86.03 \%$, respectively. Individual user accuracy and producer accuracy of all the classes of NDVI and MNDWI images are presented in Table 4.

3.3.3.2 Change Detection Change detection refers to the procedure of determining transformations of a phenomenon or condition by examining it at different periods (Singh 1989). Change detection processes can be categorized under three major headings: (1) multi-date data classification, (2) post-classification comparison, and (3) image enhancement on the basis of data variations processes and the analysis method (Mas 1999). The post-classification comparison technique was applied to assimilate three change scenes for the years 1989, 1999 and 2009 dependent on 2019 in this study. It contains the classification of each of the temporal (before and after) images autonomously to ascertain areas where changes have happened by discriminating the corresponding pixel (thematic) labels (Alsalman 2012). ENVI 5.3 Thematic Change Workflow tool was generated to determine change detection in NDVI and MNDWI maps of the study area. This tool examines the conversion dynamics of a specific landcover class to a different class at a particular range. Classified images of NDVI and MNDWI for the years 1989, 1999 and 2009 were imported as time 1 images independently, while the image of 2019 was imported as time 2 images for getting the changing scene of the previous three dates based on the 2019 image. The post-classification technique is the most apparent change detection process that is important for comparing classified images (Abd El-Kawy et al. 2011).

\section{Result and Discussion}

\subsection{LULC Scenario of the Lakshmibaur-Nalair Haor}

This study has analyzed LULC in Lakshmibaur-Nalair Haor to observe the changing pattern over the past three decades. Figures 8 and 9 display the classified NDVI and MNDWI maps for Lakshmibaur-Nalair Haor for the years
1989, 1999, 2009 and 2019. Additionally, areas in hectares (ha) and percentage of NDVI and MNDWI classes of the study site are exhibited on Tables 5 and 6, sequentially. The outcome of satellite image processing shows that the NDVI classifies this area into four classes: bare soil, cropland, vegetation (that indicates swamp forest and village vegetation) and no-vegetation which includes deep water and shallow water class of the MNDWI class. The MNDWI classifies the region into three classes: shallow water, deep water and non-water surface (which comprises vegetation, cropland and bare soil of the NDVI together). We plotted charts to display the areas in hectares of numerous NDVI and MNDWI classes over the three decades presented in the Figs. 10 and 11.

The detailed LULC scenario of the Lakshmibaur-Nalair Haor is introduced as follows:

Vegetation: During the study period, vegetation, including swamp forest and village vegetation, found as concentrated in the smallest portion of the study area. Land covered by vegetation was 695.79 ha (11.83\%) in 1989 . However, its covered area has reduced by 206.19 ha (3.49\%) in 2019. This land cover type has decreased by $8.34 \%$ at an average of 16.32 ha/year between 1989 and 2019. During the field visit, the local villagers reported that expansion of agricultural land is the main cause for the decrease of vegetation coverage in this research site. Cutting trees from the swamp forest is another reason for reducing vegetation (Deshwara and Eagle 2017).

Cropland: It is one of the land-use classes which displays the dramatic expansion over the 30 years. The cropland area increased from 1391.58 ha $(23.65 \%)$ in 1989 to 3120.32 ha $(53.04 \%)$ in 2019 . This class has increased by 1728.74 ha $(29.39 \%)$ with a mean rate of 57.62 ha/ year from 1989 to 2019. However, this growth was not consistant during all the years studied. Though growing initially, cropland area reduced from 2889.18 ha $(49.11 \%)$ in 1999 to 1135.08 ha $(19.29 \%)$ in 2009 . Once again, from 2009 to 2019 , it expanded from 1135.08 ha to 3120.32 ha. 


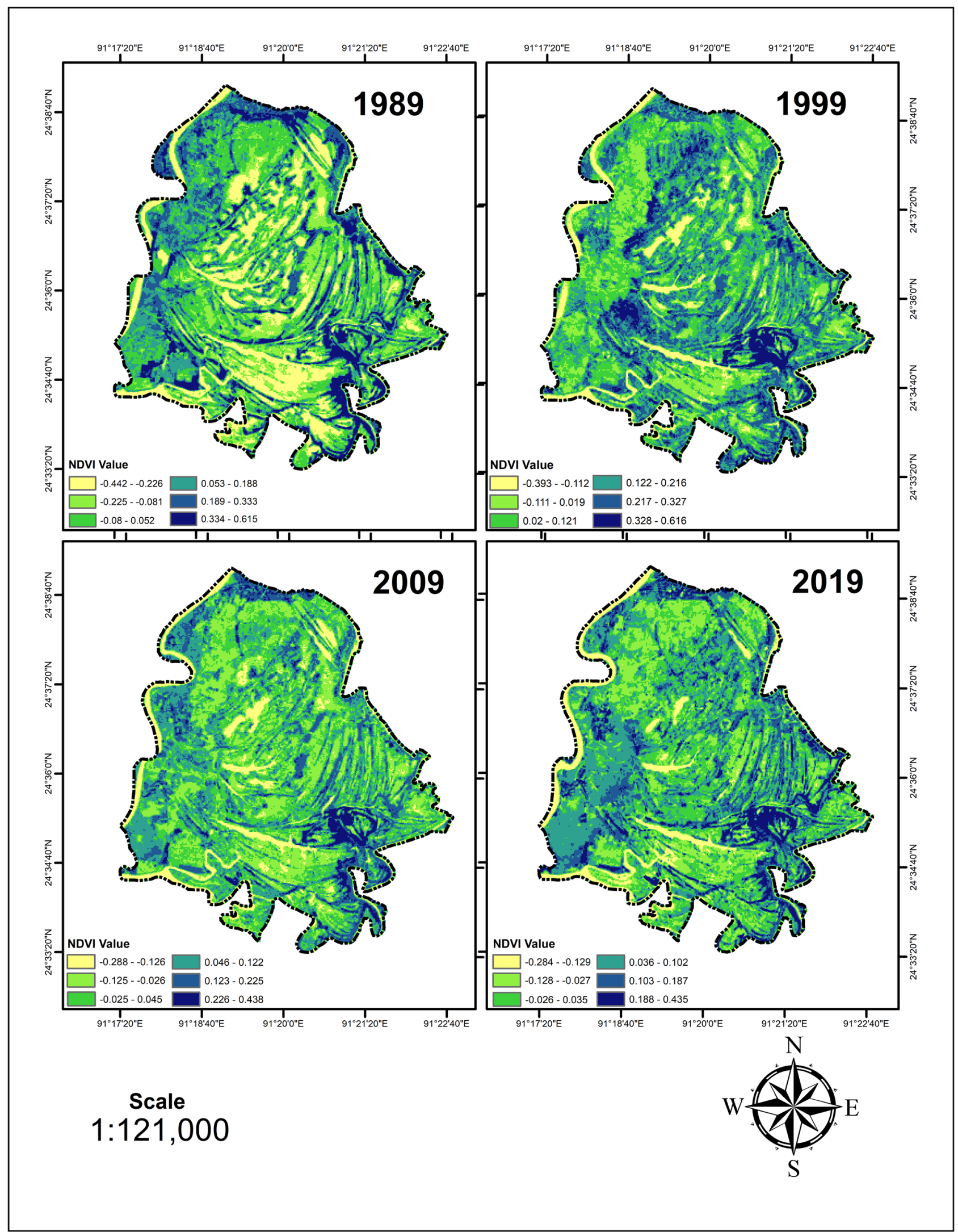

Fig. 6 Temporal NDVI images of Lakshmibaur-Nalair Haor for the year of 1989, 1999, 2009 and 2019 


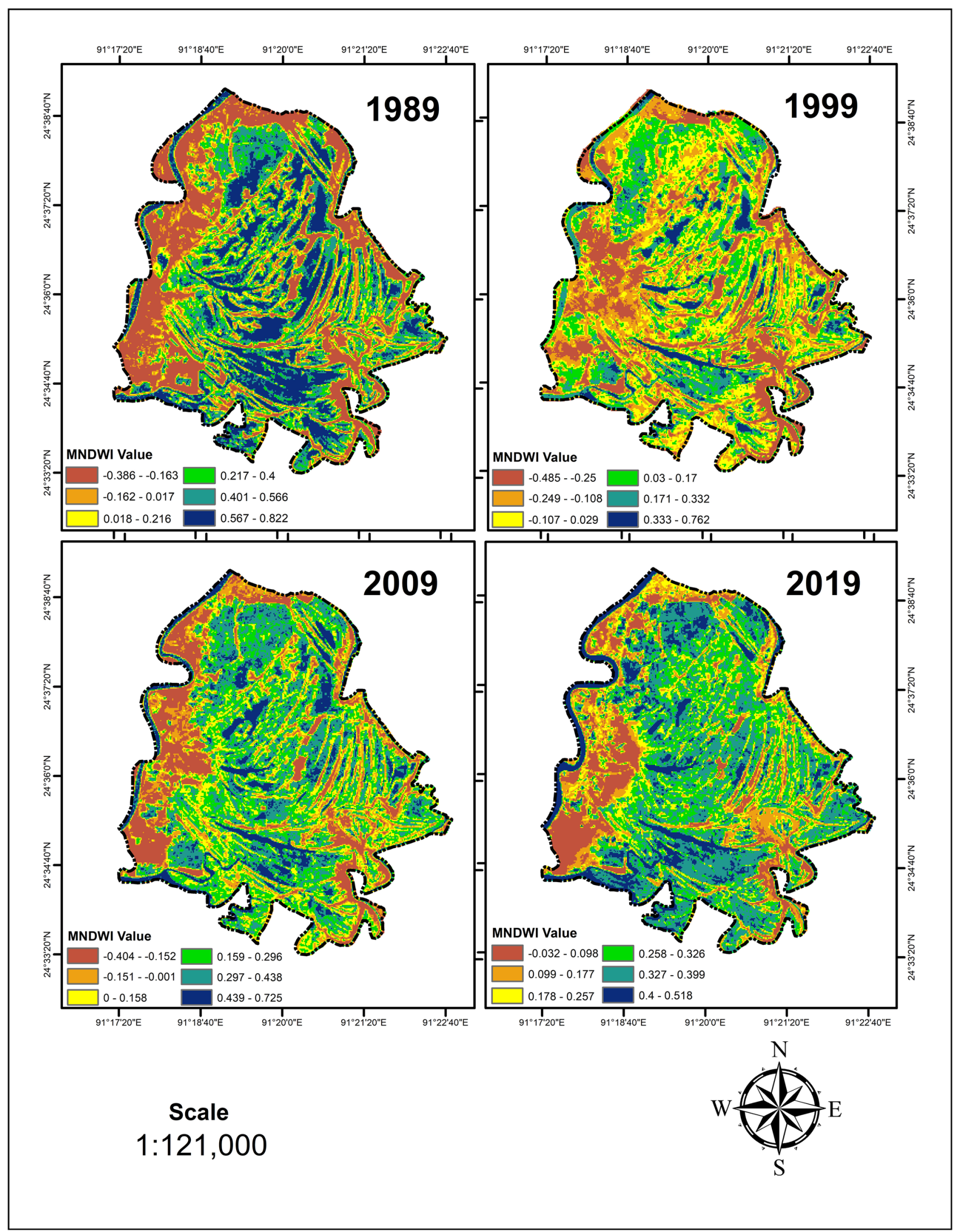

Fig. 7 Temporal MNDWI images of Lakshmibaur-Nalair Haor for the year of 1989, 1999, 2009 and 2019 
Table 3 NDVI and MNDWI classes for Lakshmibaur-Nalair Haor

\begin{tabular}{llll}
\hline Values of NDVI & Classes & $\begin{array}{l}\text { Values of } \\
\text { MNDWI }\end{array}$ & Classes \\
\hline-1 to 0 & No-vegetation & -1 to 0 & $\begin{array}{c}\text { Non-water } \\
\text { surface } \\
\text { Shallow water }\end{array}$ \\
0 to 0.1 & Bare soil & 0 to 0.3 & Deep water \\
0.1 to 0.3 & Crop land & 0.3 to 1 & \\
0.3 to 1 & Vegetation & & \\
\hline
\end{tabular}

Bare soil: It is another land type that shows an upward trend over the three decades. The entire area of bare soil was incremented from 831.24 ha (14.13\%) in 1989 to 1955.62 ha $(33.24 \%)$ in 2019. However, in 2009, it has displayed the highest cover of 2005.38 ha compared to the other three years $(1989,1999$ and 2019). It has increased by 1124.38 ha $(27.99 \%)$ with an average rate of $37.48 \mathrm{ha} /$ year between 1989 and 2019.

Deep water: Deep water was the primary land cover type in 1989 which comprised 2673.54 ha $(45.44 \%)$ of the study area. This indicates that approximately half of the study area was covered by deep water about 30 years ago. However, deep water exhibits noticeable shrinkage over the last 30 years. The total extent of deep water decreased from 2673.54 ha (45.44\%) in 1989 to 464.94 ha (7.9\%) in 2019. The studied haor area has lost 2208.6 ha (37.54\%) deep water body at a mean rate of 73.62 ha/year from 1989 to 2019 . We noticed a rapid decrease in the deep water from 2673.54 ha $(45.44 \%)$ in 1989 to 774.63 ha $(13.17 \%)$ in 1999. Then the deep water body decreased gradually from 774.63 ha (13.17\%) in 1999 to 464.94 ha (7.9\%) in 2019.

Shallow water: This waterbody type has shown a gradual increasing trend from 1989 to 2019. About 1113.12 ha (18.92\%) area comprised the overall amount of shallow water body in 1989. It increased from 1113.12 ha (18.92\%) in 1989 to $3786.3 \mathrm{ha}(64.36 \%$ ) in 2019. In 2009, the extent of shallow water was 3534.12 ha (60.08\%), which continued to increase up to 2019 , covering 3786.3 ha $(64.36 \%)$ area. The study area has gained 2673.18 ha (45.44\%) shallow water body with an average value of 89.106 ha/year over the last 3 decades.

\subsection{Change Detection}

Change detection was performed to indicate the changes that are identified for the temporal dates 1989, 1999 and 2009 of the NDVI and MNDWI classes with respect to the year 2019 (shown in Figs. 12, 13). Tables 7 and 8 display the statistics of change detection of the NDVI and MNDWI, respectively. The changing area has been stated in hectare unit and the percentage of change has been measured based on the total land area of the study site. We have plotted graphs of the change detection to display the variations in the three change sights, 1989-2019, 1999-2019 and 2009-2019 of the NDVI and MNDWI classes (presented in Figs. 14, 15). Results obtained from these change detection show significant LULC changes in Lakshmibaur-Nalair Haor over the last three decades.

For the period 1989-2019, significant changes were observed from no-vegetation to bare soil, where no-vegetation indicates water surface area (deep water and shallow water). About 1531.97 ha of no-vegetation area has been converted to bare soil, while only 19.26 ha of the bare soil was converted to water surface area. Another major conversion occurred over the last 30 years is that about 1137.45 ha of the haor area converted from no-vegetation to crop land. About 2349.65 ha area shifted from deep water to shallow water. From the total vegetation, about 520.47 ha area changed to cropland, 121.41 ha area remained unchanged and 60.22 ha area changed to bare soil. From the total crop land area, 238.05 ha area converted to bare soil and 1098.94 ha area remained unchanged. About 180.74 ha areas of deep water altered to non-water surface area and 320.59 ha area stayed unchanged. However, 143.64 ha area shifted to non-water surface area from the total shallow water, 719.53 ha area remained unchanged and 13.78 ha area converted to deep water.
Table 4 User and producer accuracy assessment of NDVI and MNDWI classified maps of 2019

\begin{tabular}{lllcccc}
\hline Classification & Class name & $\begin{array}{l}\text { Reference } \\
\text { total }\end{array}$ & $\begin{array}{l}\text { Classified } \\
\text { total }\end{array}$ & $\begin{array}{l}\text { Number } \\
\text { correct }\end{array}$ & $\begin{array}{l}\text { User accu- } \\
\text { racy (\%) }\end{array}$ & $\begin{array}{l}\text { Producer } \\
\text { accuracy } \\
(\%)\end{array}$ \\
\hline \multirow{2}{*}{ NDVI } & No-vegetation & 17 & 16 & 16 & 100 & 94.12 \\
& Bare soil & 11 & 9 & 7 & 78.98 & 65.67 \\
& Cropland & 17 & 17 & 14 & 82.35 & 82.35 \\
& Vegetation & 7 & 8 & 6 & 75 & 85.71 \\
\multirow{3}{*}{ MNDWI } & Non-water surface & 24 & 23 & 22 & 95.65 & 91.67 \\
& Shallow water & 14 & 15 & 12 & 80.00 & 85.71 \\
& Deep water & 13 & 12 & 11 & 91.67 & 84.62 \\
\hline
\end{tabular}




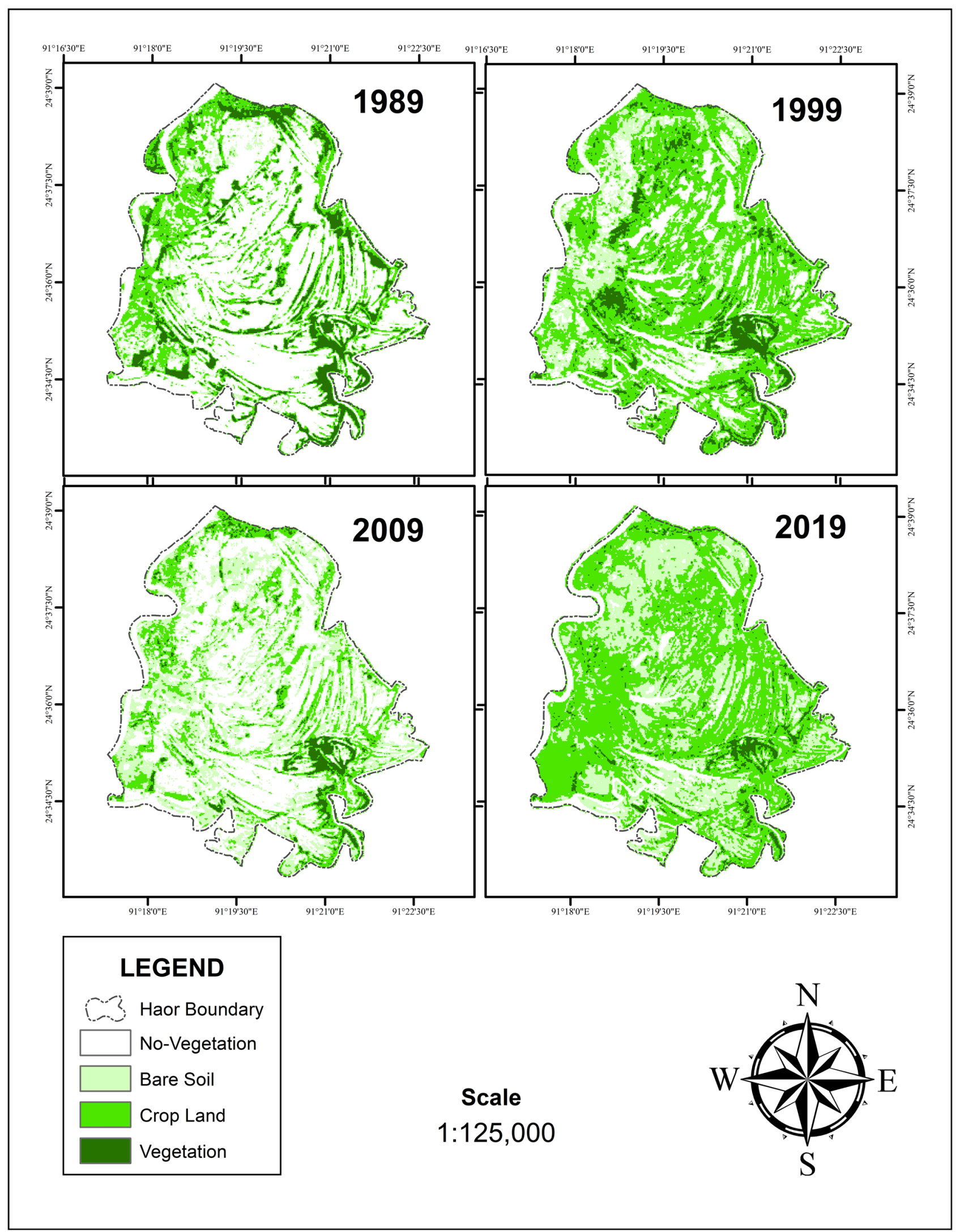

Fig. 8 Classified NDVI Map of Lakshmibaur-Nalair Haor (1989, 1999, 2009 and 2019) 


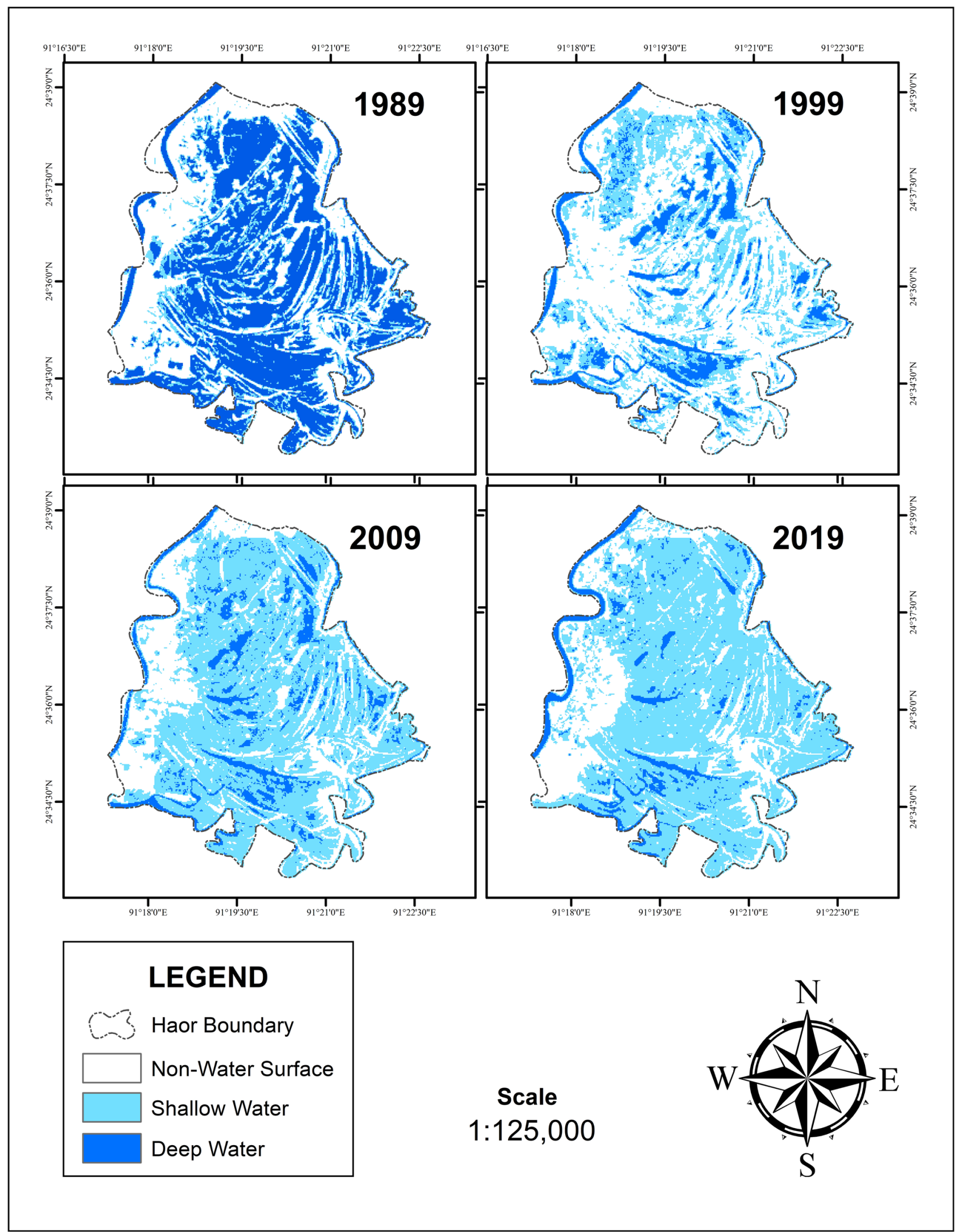

Fig. 9 Classified MNDWI Map of Lakshmibaur-Nalair Haor (1989, 1999, 2009 and 2019) 
Table 5 Area (ha) and percent of each NDVI classes of Lakshmibaur-Nalair Haor

\begin{tabular}{|c|c|c|c|c|c|c|c|c|}
\hline \multirow[t]{2}{*}{ Class Name } & \multicolumn{2}{|l|}{1989} & \multicolumn{2}{|l|}{1999} & \multicolumn{2}{|l|}{2009} & \multicolumn{2}{|l|}{2019} \\
\hline & Area (ha) & $\%$ & Area (ha) & $\%$ & Area (ha) & $\%$ & Area (ha) & $\%$ \\
\hline No-vegetation & 2964.33 & 50.39 & 1163.97 & 19.78 & 2517.3 & 42.79 & 600.41 & 10.21 \\
\hline Bare soil & 831.24 & 14.13 & 1315.26 & 22.36 & 2005.38 & 34.09 & 1955.62 & 33.24 \\
\hline Crop land & 1391.58 & 23.65 & 2889.18 & 49.11 & 1135.08 & 19.29 & 3120.32 & 53.04 \\
\hline Vegetation & 695.79 & 11.83 & 514.53 & 8.75 & 225.18 & 3.83 & 206.59 & 3.51 \\
\hline Total & 5882.94 & 100 & 5882.94 & 100 & 5882.94 & 100 & 5882.94 & 100 \\
\hline
\end{tabular}

Table 6 Area (ha) and percent of each MNDWI classes of Lakshmibaur-Nalair Haor

\begin{tabular}{|c|c|c|c|c|c|c|c|c|}
\hline \multirow[t]{2}{*}{ Class Name } & \multicolumn{2}{|l|}{1989} & \multicolumn{2}{|l|}{1999} & \multicolumn{2}{|l|}{2009} & \multicolumn{2}{|l|}{2019} \\
\hline & Area (ha) & $\%$ & Area (ha) & $\%$ & Area (ha) & $\%$ & Area (ha) & $\%$ \\
\hline Non-water surface & 2096.28 & 35.64 & 3314.25 & 56.34 & 1681.92 & 28.58 & 1631.7 & 27.74 \\
\hline Shallow water & 1113.12 & 18.92 & 1794.06 & 30.49 & 3534.12 & 60.08 & 3786.3 & 64.36 \\
\hline Deep water & 2673.54 & 45.44 & 774.63 & 13.17 & 666.9 & 11.34 & 464.94 & 7.9 \\
\hline Total & 5882.94 & 100 & 5882.94 & 100 & 5882.94 & 100 & 5882.94 & 100 \\
\hline
\end{tabular}

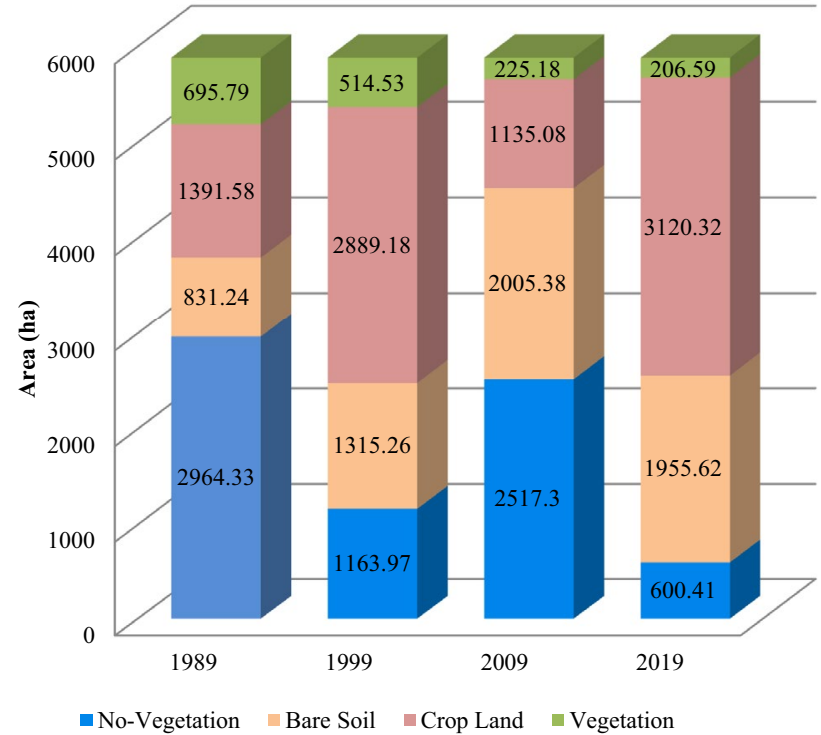

Fig. 10 Area (ha) of NDVI classes

This study outcomes exhibit that the water surface area of Lakshmibaur-Nalair Haor has been changed during the period examined. Mainly, deep water area has been decreased dramatically and converted to shallow water area. The reason behind this conversion, claimed by the local villagers during the field visit, is the dam construction on the upstream which is one of the influential factors of the increment of siltation rate and the reduction of the navigability in the surrounding river system. The change statistics also show that shallow water area has augmented by around $45 \%$ over 30 years period, which is more amiable for agricultural activities. Consequently, the cropland of the study area has incremented by approximately $30 \%$

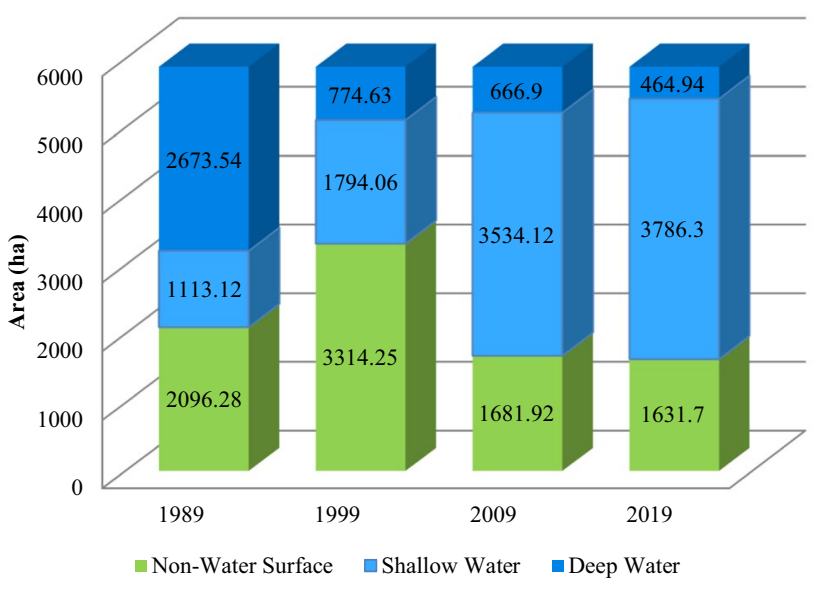

Fig. 11 Area (ha) of MNDWI classes

over the last three decades due to increased population and food demand. Moreover, swamp forest and village vegetation stated as vegetation class in this study has been declined gradually. During the field visit, local community also reported that fishing activity allow them to gain more profit than agriculture because fish value is higher than rice whereas haor area allow them to pursue single cropping within a year. Fish diversity in the haor area was also declined for degradation of the deep water area, the local residence reported. The vegetation of the study area was also decreased because of increasing population pressure. It would be worth mentioning that similar trend of LULC changes has also been found in two other hoars in Bangladesh, namely Tanguar haor and Hakaluki haor-situated in the same haor basin. Tanguar haor and Hakaluki haor have also experienced reduced water bodies and increased agricultural lands over the last thirty years 


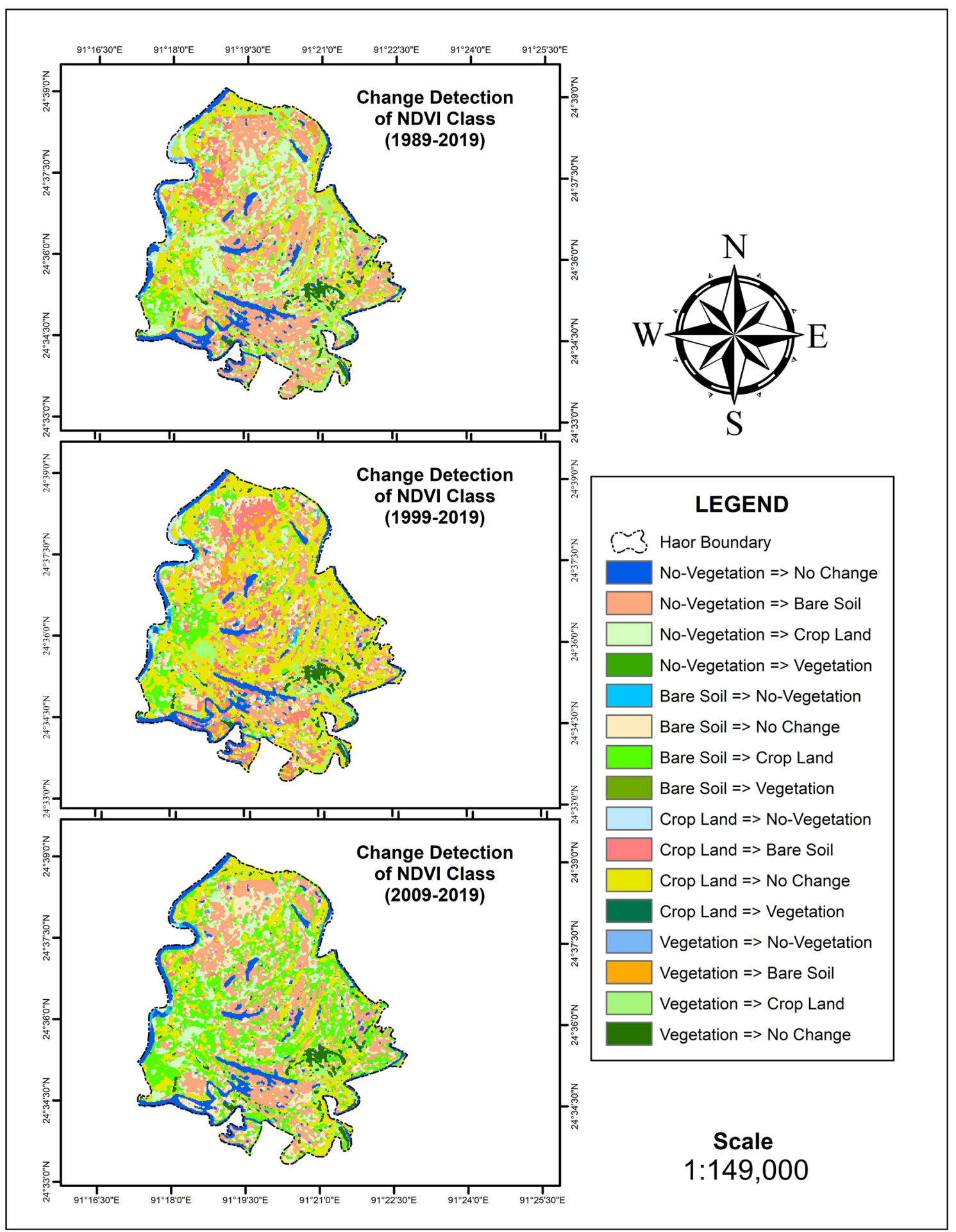

Fig. 12 NDVI change detection map of Lakshmibaur-Nalair Haor on the year of 1989, 1999 and 2009 with reference to the year of 2019

(Haque and Basak 2017; Uddin et al. 2013). These studies clearly indicate that the land cover of haor regions has been changed dramatically with an increased demographic pressure. Haor ecosystems are being impacted due to lack of proper monitoring and management. This current study contributes to understand such changes by comparing past and present scenarios. So, accurate and up-to-date information is significantly important for continuous monitoring of the haor region and more sustainable management of haor resources. 


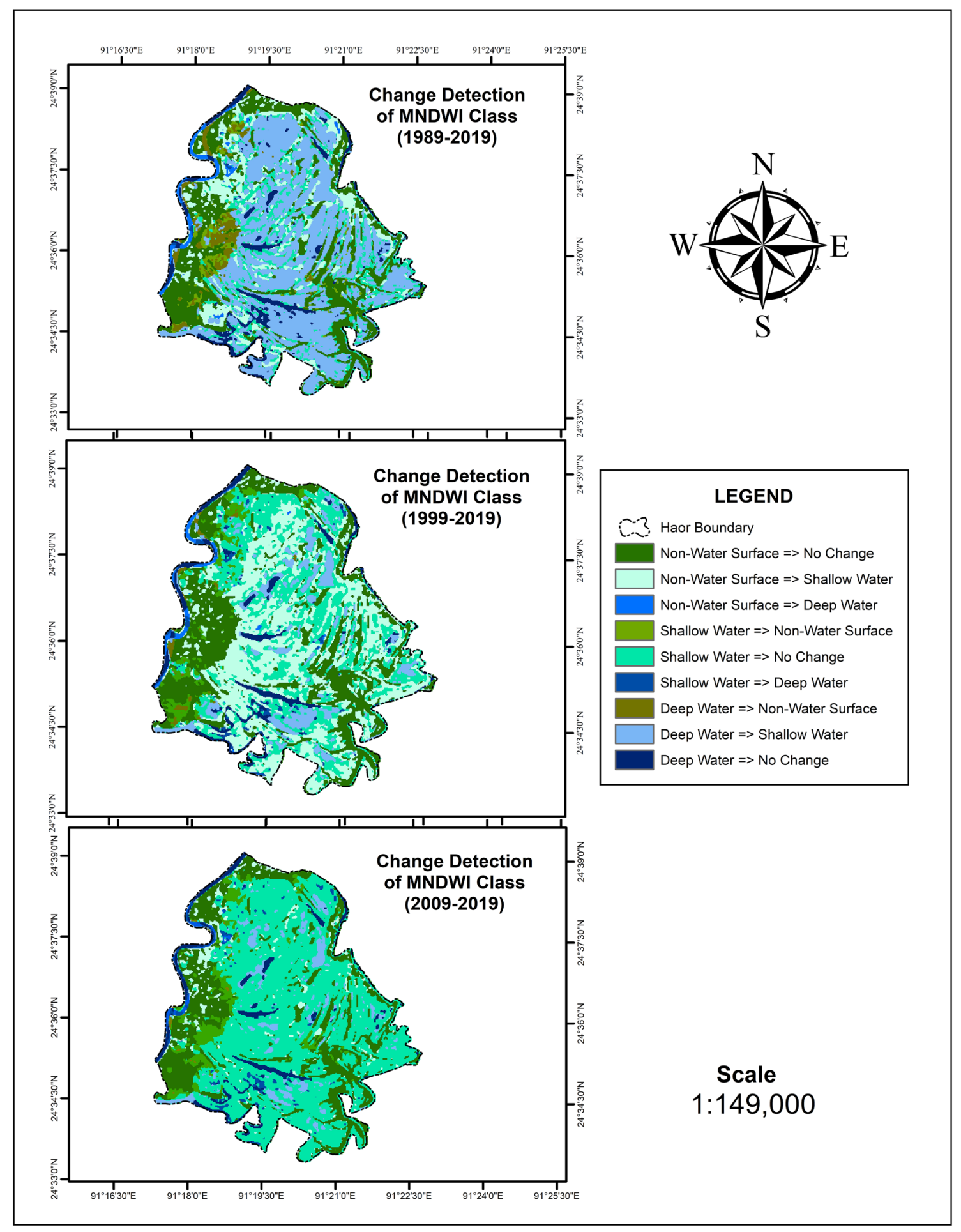

Fig. 13 MNDWI change detection map of Lakshmibaur-Nalair Haor on the year of 1989, 1999 and 2009 based on 2019, from top to bottom, sequentially 
Table 7 Change detection of NDVI classes for the years of 1989, 1999 and 2009 with respect to 2019
Table 8 Change detection of MNDWI classes for the years of 1989,1999 and 2009 with respect to 2019

\begin{tabular}{|c|c|c|c|c|c|c|}
\hline \multirow[t]{2}{*}{ Class name } & \multicolumn{2}{|l|}{1989} & \multicolumn{2}{|l|}{1999} & \multicolumn{2}{|l|}{2009} \\
\hline & Area (ha) & $\%$ & Area (ha) & $\%$ & Area(ha) & $\%$ \\
\hline No-vegetation $\Rightarrow$ no change & 514.74 & 8.75 & 473.52 & 8.05 & 558.44 & 9.49 \\
\hline No-vegetation $\Rightarrow$ bare soil & 1531.97 & 26.04 & 464.14 & 7.89 & 1326.78 & 22.55 \\
\hline No-vegetation $\Rightarrow$ crop land & 1137.45 & 19.34 & 231.46 & 3.93 & 664.85 & 11.3 \\
\hline No-vegetation $\Rightarrow$ vegetation & 5.13 & 0.09 & 2.63 & 0.04 & 1.88 & 0.03 \\
\hline Bare soil $\Rightarrow$ no-vegetation & 19.26 & 0.33 & 70.6 & 1.2 & 38.08 & 0.65 \\
\hline Bare soil $\Rightarrow$ no change & 145.89 & 2.48 & 531.27 & 9.03 & 538.59 & 9.16 \\
\hline Bare soil $\Rightarrow$ crop land & 388.47 & 6.6 & 528.86 & 8.99 & 1395.54 & 23.72 \\
\hline Bare soil $\Rightarrow$ vegetation & 4.24 & 0.07 & 3.47 & 0.06 & 4.05 & 0.07 \\
\hline Crop land $\Rightarrow$ no-vegetation & 54.38 & 0.92 & 49.15 & 0.84 & 10.55 & 0.18 \\
\hline Crop land $\Rightarrow$ bare soil & 238.05 & 4.05 & 776.89 & 13.22 & 58.68 & 0.99 \\
\hline Crop land $\Rightarrow$ no change & 1098.94 & 18.68 & 2266.84 & 38.53 & 1023.93 & 17.41 \\
\hline Crop land $\Rightarrow$ vegetation & 31.7 & 0.57 & 52.75 & 0.89 & 51.53 & 0.88 \\
\hline Vegetation $\Rightarrow$ no-vegetation & 10.62 & 0.18 & 4.99 & 0.08 & 3.45 & 0.06 \\
\hline Vegetation $\Rightarrow$ bare soil & 60.22 & 1.02 & 68.94 & 1.17 & 9.18 & 0.16 \\
\hline Vegetation $\Rightarrow$ crop land & 520.47 & 8.82 & 261.65 & 4.45 & 88.33 & 1.5 \\
\hline Vegetation $\Rightarrow$ no change & 121.41 & 2.06 & 95.78 & 1.63 & 109.08 & 1.85 \\
\hline Total & 5882.94 & 100 & 5882.94 & 100 & 5882.94 & 100 \\
\hline
\end{tabular}

\begin{tabular}{|c|c|c|c|c|c|c|}
\hline \multirow[t]{2}{*}{ Class name } & \multicolumn{2}{|l|}{1989} & \multicolumn{2}{|l|}{1999} & \multicolumn{2}{|l|}{2009} \\
\hline & Area (ha) & $\%$ & Area (ha) & $\%$ & Area (ha) & $\%$ \\
\hline Non-water surface $\Rightarrow$ no change & 1338.4 & 22.75 & 1406.34 & 23.91 & 1287.09 & 21.88 \\
\hline Non-water surface $\Rightarrow$ shallow water & 721.75 & 12.27 & 1919.84 & 32.63 & 239.1 & 4.07 \\
\hline Non-water surface $\Rightarrow$ deep water & 94.86 & 1.61 & 57.69 & 0.98 & 33.3 & 0.57 \\
\hline Shallow water $\Rightarrow$ non-water surface & 143.64 & 2.44 & 192.54 & 3.27 & 315.81 & 5.38 \\
\hline Shallow water $\Rightarrow$ no change & 719.53 & 12.23 & 1468.89 & 24.97 & 3327.3 & 56.56 \\
\hline Shallow water $\Rightarrow$ deep water & 13.78 & 0.23 & 84.36 & 1.43 & 109.08 & 1.82 \\
\hline Deep water $\Rightarrow$ non-surface water & 180.74 & 3.08 & 47.76 & 0.82 & 19.23 & 0.33 \\
\hline Deep water $\Rightarrow$ shallow water & 2349.65 & 39.94 & 439.66 & 7.47 & 295.04 & 5.02 \\
\hline Deep water $\Rightarrow$ no change & 320.59 & 5.45 & 265.86 & 4.52 & 256.99 & 4.37 \\
\hline Total & 5882.94 & 100 & 5882.94 & 100 & 5882.94 & 100 \\
\hline
\end{tabular}

\section{Conclusion}

Vegetation and water body are the regular features of wetlands. NDVI and MNDWI analysis took place to examine the similar variation among the variables of vegetation and water body. The unsupervised classification technique has been generated to produce classified maps of NDVI and MNDWI. The change detection process has been applied to determine variations in coverage of the area of all the resultant classes. This study demonstrated that the study location's deep water surface area declined at an alarming rate ( 74 ha/year) over the last 30 years. Indeed, comparing with 1989 , the current deep water area decreased by $37.54 \%$ of which about $40 \%$ also transformed into shallow water area. Thus, shallow water displayed an increasing trend during the study period. Vegetation showed a downward trend between 1989 and 2019; it decreased by $8.34 \%$ over the study period. On the other hand, cropland appeared as a land-use class showing significant expansion. Croplands increased by $29.39 \%$ over the three decades due to rising shallow water (which is favorable for agriculture activities in the dry season) and increased population pressure (which 
Fig. 14 Area (ha) of NDVI change detection classes for the years of 1989, 1999 and 2009 with reference to 2019

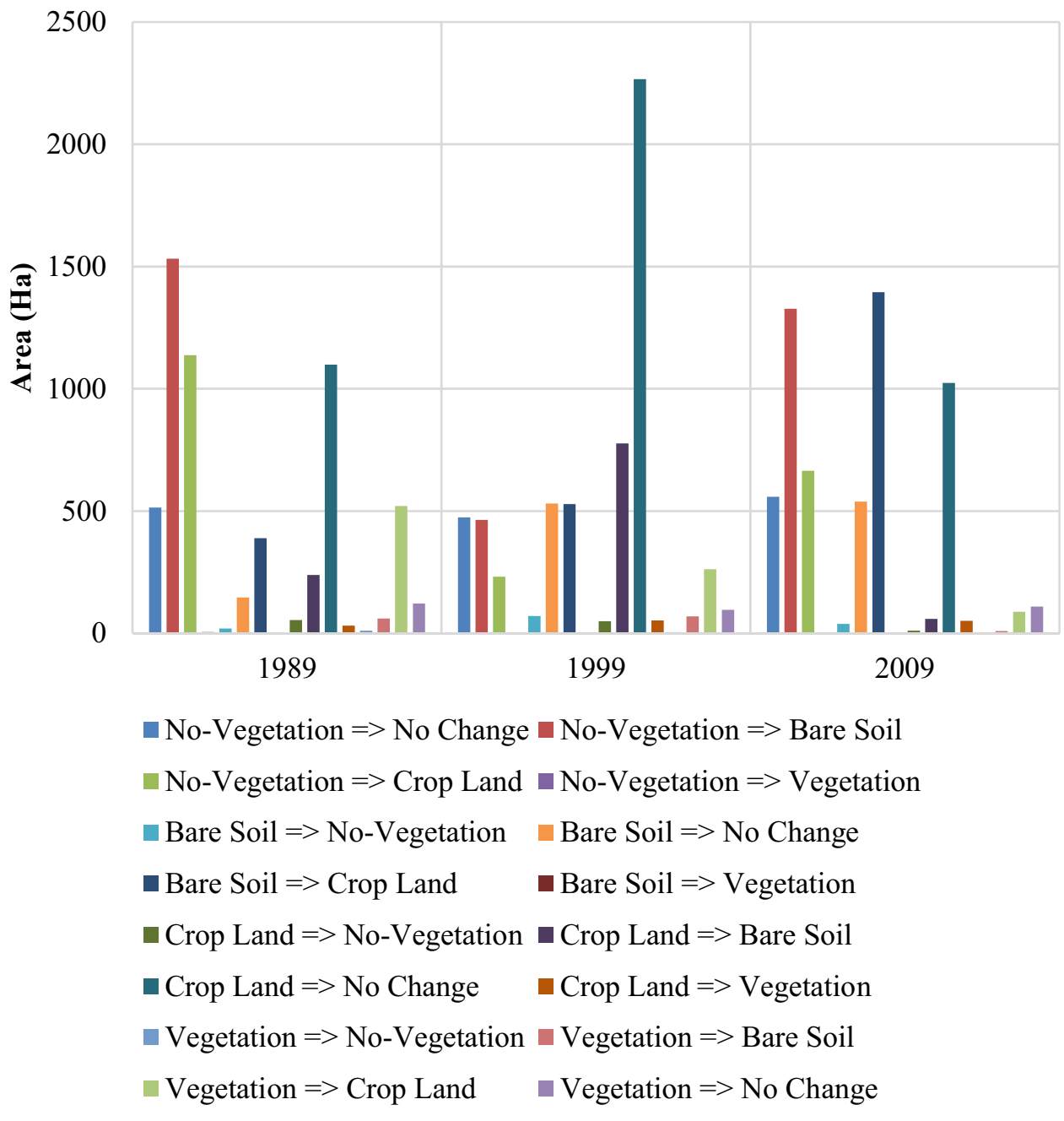

attracts more agriculture activities). Bare soil also displayed an upward trend between 1989 and 2019. Studies including Chakraborty et al. (2018) and Pal and Saha (2018) claimed that construction of dams curtailed discharge below the dam and squeezed wetland areas in some other locations in Bangladesh and neighbouring India. Though no scientific evidence available to establish such a connection as the main reason for changes in water depths in the current study area, as mentioned before, local villagers during this fieldwork claimed that dam construction on the upstream is changing water depth in the studied haor area. Both haor managers and future researchers will have the responsibility to undertake actions to examine and mitigate the potential impacts of such drivers altering hydrological feature in the study area. However, this baseline study illustrates LULC change of a freshwater wetland using spatio-temporal analysis of the Lakshmibaur-Nalair Haor area. Future studies can continue monitoring trends in LULC dynamics through LULC 
Fig. 15 Area (ha) of MNDWI change detection classes for the years of 1989, 1999 and 2009 with reference to 2019

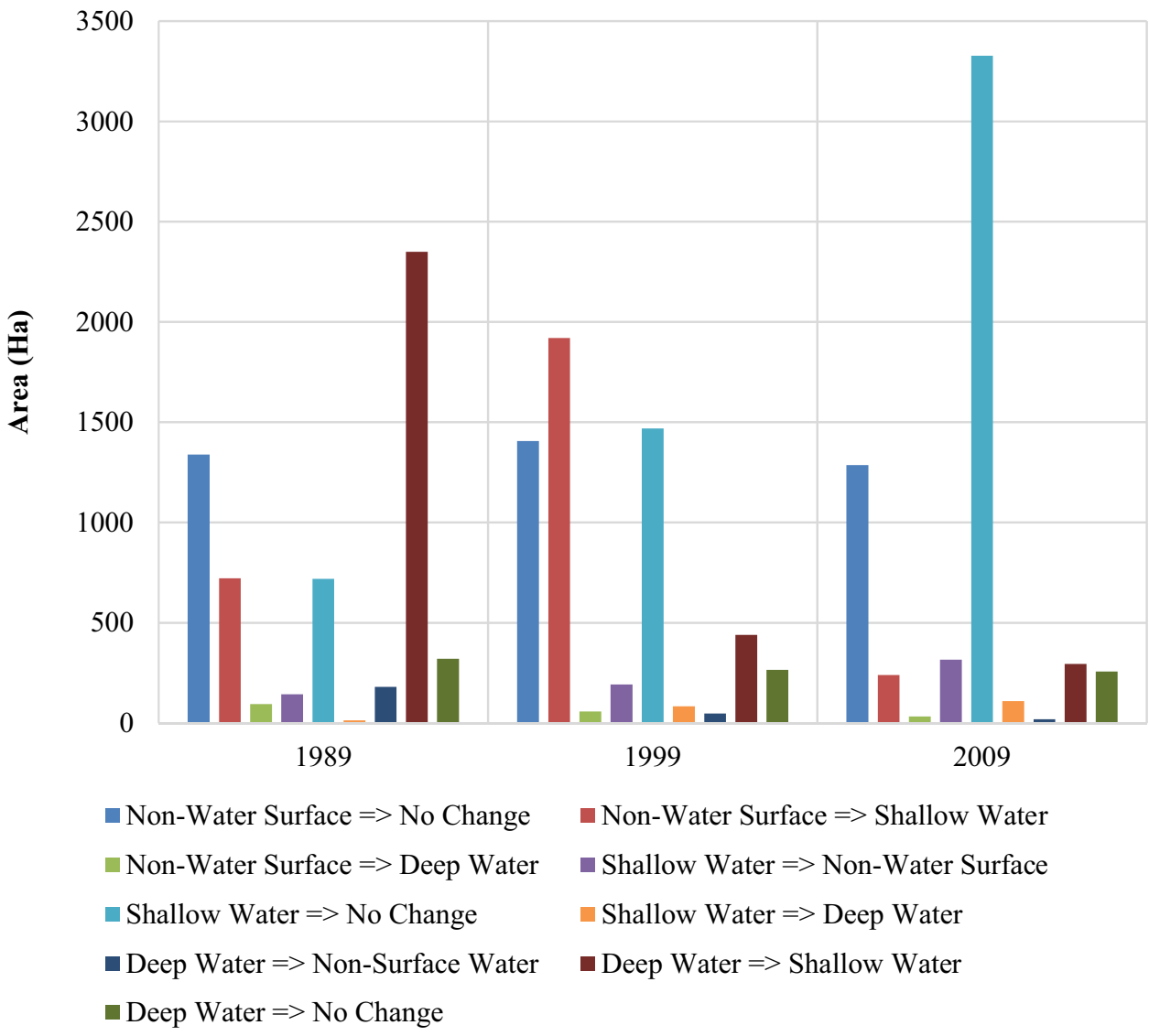

modeling which is an essential tool for improved haor management. The findings of this study would be significant for biodiversity conservation and environmental decision making in the context of Lakshmibaur-Nalair Haor and other similar settings.

Acknowledgements The authors are grateful to USGS for providing free Landsat imageries for this research. They are highly thankful to the local government and community of Lakshmibaur-Nalair Haor for their cordial help in surveying this region.

Funding No funding was received for conducting this study.

\section{Compliance with ethicalstandards}

Conflict of interest The authors declare that they have no conflict of interest.

Open Access This article is licensed under a Creative Commons Attribution 4.0 International License, which permits use, sharing, adaptation, distribution and reproduction in any medium or format, as long as you give appropriate credit to the original author(s) and the source, provide a link to the Creative Commons licence, and indicate if changes were made. The images or other third party material in this article are included in the article's Creative Commons licence, unless indicated otherwise in a credit line to the material. If material is not included in the article's Creative Commons licence and your intended use is not permitted by statutory regulation or exceeds the permitted use, you will need to obtain permission directly from the copyright holder. To view a copy of this licence, visit http://creativecommons.org/licenses/by/4.0/.

\section{References}

Abd El-Kawy OR, Rød JK, Ismail HA, Suliman AS (2011) Land use and land cover change detection in the western Nile delta of Egypt using remote sensing data. Appl Geogr 31:483-494

Alsalman AS, Mattar HE, Ali AE (2012) Comparative study of change detection and urban expansion using multi-date multi-source data: a case study of Greater Khartoum. J King Abdulaziz Univ 23(2):139-172. https://doi.org/10.4197/eng.23-2.8

Ahmed B (2011) Urban land cover change detection analysis and modeling spatio-temporal growth dynamics using remote sensing and GIS techniques: a case study of Dhaka. NOVA Information Management School (NIMS), Bangladesh

Akter A (2011) People's perceptions of environmental pollution in Mokosh Beel, Bangladesh. http://dlc.dlib.indiana.edu/dlc/bitst ream/handle/10535/7300/1331.pdf?sequence=1\&isAllowed=y Accessed 25 Nov 2020

Alam MK, Hasan AKM, Khan MR, Whitney JW (1990) Geological Map of Bangladesh. Geological Survey of Bangladesh. Dhaka

Alam MS, Quayum M, Islam M (1970) Crop production in the Haor Areas of Bangladesh: insights from farm level survey. Agric 8:88-97. https://doi.org/10.3329/agric.v8i2.7582

Alam A, Bhat MS, Maheen M (2020) Using Landsat satellite data for assessing the land use and land cover change in Kashmir valley. GeoJournal 85(6):1529-1543 
Ali F (2014) Wetland biodiversity: a case study of Tanguar Haor. In: Fourkan's Artic. http://fourkansarticle.blogspot.com/2014/01/ wetland-biodiversity-case-study-of.html. Accessed 25 Oct 2019

Alphan H, Derse MA (2013) Change detection in Southern Turkey using normalized difference vegetation index (NDVI). J Environ Eng Landsc Manag 21:12-18. https://doi.org/10.3846/16486897. 2012.663091

Alqurashi A, Kumar L (2013) Investigating the use of remote sensing and GIS techniques to detect land use and land cover change: a review. Adv Remote Sens. https://doi.org/10.4236/ars.2013.22022

BHWDB (2012) Master plan of Haor area volume II main report. Ministry of Water Resources, Government of the People's Republic of Bangladesh. Dhaka

Barakat A, Ouargaf Z, Khellouk R et al (2019) Land use/land cover change and environmental impact assessment in béni-mellal district (morocco) using remote sensing and GIS. Earth Syst Environ 3:113-125. https://doi.org/10.1007/s41748-019-00088-y

Bennett S, Scott D, Karim A et al (1995) Wetland resources specialist study, northeast regional water management plan. Bangladesh Flood Action Plan (FAP)-6, Bangladesh

Brammer H (2012) Physical geography of Bangladesh. The University Press Ltd. Dhaka

Brammer H (1996) The geography of soils of Bangladesh. The University of Press Ltd. Dhaka

Chamling M, Bera B (2020) Spatio-temporal patterns of land use/ land cover change in the Bhutan-Bengal foothill region between 1987 and 2019: study towards geospatial applications and policy making. Earth Syst Environ 4:117-130. https://doi.org/10.1007/ s41748-020-00150-0

Chakraborty R, Talukdar S, Basu T, Pal S (2018) Habitat identity crisis caused by the riparian wetland squeeze in Tangon River Basin, Barind Region, India. Spat Inform Res 26(5):507-516

Cong P, Chen K, Qu L, Han J (2019) Dynamic changes in the wetland landscape pattern of the Yellow River Delta from 1976 to 2016 based on satellite data. Chin Geogr Sci 29(3):372-381. https://doi. org/10.1007/s11769-019-1039-x

Cowardin LM, Golet FC (1995) US Fish and Wildlife Service 1979 wetland classification: a review. Vegetatio 118:139-152. https:// doi.org/10.1007/BF00045196

Department of Bangladesh Haor and Wetlands Development (2016) Classification of wetlands of Bangladesh volume I: main report. Ministry of Water Resources, Government of the People's Republic of Bangladesh, Dhaka

Deshwara M, Eagle A (2017) Habiganj swamp forest under threat. The daily star. https://www.thedailystar.net/country/habiganjswamp-forest-under-threat-1453756. Accessed 25 Oct 2019

Dugan PJ (1990) Wetland conservation: a review of current issues and required action. https://portals.iucn.org/library/node/6048. Accessed 23 Sept 2020

Eid ANM, Olatubara CO, Ewemoje TA, Farouk H, El-Hennawy MT (2020) Coastal wetland vegetation features and digital Change Detection Mapping based on remotely sensed imagery: El-Burullus Lake, Egypt. Int Soil Water Conserv Res 8:66-79. https://doi. org/10.1016/j.iswcr.2020.01.004

Elagouz MH, Abou-Shleel SM, Belal AA, El-Mohandes MAO (2020) Detection of land use/cover change in Egyptian Nile Delta using remote sensing. Egypt J Remote Sens Sp Sci 23:5762. https://doi.org/10.1016/j.ejrs.2018.10.004

Gandhi GM, Parthiban S, Thummalu N, Christy A (2015) Ndvi: vegetation change detection using remote sensing and Gis-a case study of Vellore District. Procedia Comput Sci 57:1199-1210. https://doi.org/10.1016/j.procs.2015.07.415

Guo M, Li J, Sheng C et al (2017) A review of wetland remote sensing. Sensors (switzerland) 17:777. https://doi.org/10.3390/ s17040777
Hassan MM (2017) Monitoring land use/land cover change, urban growth dynamics and landscape pattern analysis in five fastest urbanized cities in Bangladesh. Remote Sens Appl Soc Environ 7:69-83. https://doi.org/10.1016/j.rsase.2017.07.001

Haque I, Basak R (2017) Land cover change detection using GIS and remote sensing techniques: A spatio-Temporal study on Tanguar Haor, Sunamganj, Bangladesh. Egypt J Remote Sens Sp Sci 20:251-263. https://doi.org/10.1016/j.ejrs.2016.12.003

Houghton RA (1994) The worldwide extent of land-use change. Bioscience 44:305-313. https://doi.org/10.2307/1312380

Islam S (2003) Banglapedia: national encyclopedia of Bangladesh (Vol. 3). Asiatic society of Bangladesh. Dhaka

Islam SN (2010) Threatened wetlands and ecologically sensitive ecosystems management in Bangladesh. Front Earth Sci China 4(4):438-448

Islam MN, Rakib MR, Sufian MA, Raihan Sharif AHM (2018) Detection of climate change impacts on the Hakaluki Haor wetland in Bangladesh by use of remote sensing and GIS. In: Islam M, van Amstel A (eds) Bangladesh I: climate change impacts, mitigation and adaptation in developing countries. Springer, Cham

Jawak SD, Luis AJ (2013) A spectral index ratio-based Antarctic landcover mapping using hyperspatial 8-band WorldView-2 imagery. Polar Sci 7:18-38. https://doi.org/10.1016/j.polar.2012.12.002

Kaliraj S, Chandrasekar N, Ramachandran KK et al (2017) Coastal landuse and land cover change and transformations of Kanyakumari coast, India using remote sensing and GIS. Egypt J Remote Sens Sp Sci 20:169-185. https://doi.org/10.1016/j.ejrs.2017.04.003

Kalpoma KA, Nawar Arony N, Chowdhury A et al (2019) Boro rice model for HAOR region of Bangladesh based on Modis NDVI Images. In: International Geoscience and Remote Sensing Symposium (IGARSS). IEEE, Yokohama, pp 7326-7329. https://doi. org/10.1109/IGARSS.2019.8899013

Kanan AH (2016) Characterization and conservation of wetlands with global change dynamics : a case study on Ratargul Swamp Forest, Bangladesh. Master Thesis, University of Lisbon, Lisbon, Portugal. https://www.medfor.eu/sites/default/files/editor/kanan_digit al_version.pdf. Accesed 20 Sept 2020

Khan MM (2008) Functioning of local government (Union Parishad): Legal and practical constraints. http://www.dwatch-bd.org/L\&P\% 20constraints.pdf. Accessed 15 Sept 2020

Kumar L, Ghosh MK (2012) Land cover change detection of Hatiya Island, Bangladesh, using remote sensing techniques. J Appl Remote Sens 6:63608. https://doi.org/10.1117/1.JRS.6.063608

Mahdavi S, Salehi B, Granger J et al (2018) Remote sensing for wetland classification: a comprehensive review. Giscience Remote Sens 55:623-658. https://doi.org/10.1080/15481603.2017.14196 02

Mao D, Wang Z, Du B, Li L, Tian Y, Jia M, Zeng Y, Song K, Jiang M, Wang Y (2020) National wetland mapping in China: a new product resulting from object-based and hierarchical classification of Landsat 8 OLI images. ISPRS J Photogramm Remote Sens 164:11-25. https://doi.org/10.1016/j.isprsjprs.2020.03.020

Mas JF (1999) Monitoring land-cover changes: a comparison of change detection techniques. Int J Remote Sens 20:139-152. https://doi. org/10.1080/014311699213659

Mitsch WJ, Gosselink JG (1993) Wetlands, 2nd edn. Van Nostrand Reinhold, New York

Mozumder C, Tripathi NK, Tipdecho T (2014) Ecosystem evaluation (1989-2012) of Ramsar wetland Deepor Beel using satellitederived indices. Environ Monit Assess 186:7909-7927. https:// doi.org/10.1007/s10661-014-3976-2

Nishat A (1993) Freshwater wetlands in Bangladesh: status and issues. In: Nishat A, Hussain Z, Roy Monoj K, Karim A (eds) Freshwater wetlands in Bangladesh: issues and approaches for management. IUCN, Gland, pp 9-22 
Ozesmi SL, Bauer ME (2002) Satellite remote sensing of wetlands. Wetlands Ecol Manage 10(5):381-402

Pal S, Saha TK (2018) Identifying dam-induced wetland changes using an inundation frequency approach: the case of the Atreyee River basin of Indo-Bangladesh. Ecohydrol Hydrobiol 18(1):66-81

Rahimi L, Malekmohammadi B, Yavari AR (2020) Assessing and modeling the impacts of wetland land cover changes on water provision and habitat quality ecosystem services. Nat Resour Res 29:3701-3718. https://doi.org/10.1007/s11053-020-09667-7

Rasheed KBS (2008) Bangladesh: resource and environment profile, 2nd edn. A H Development Publishing House, Dhaka

Rawat JS, Kumar M (2015) Monitoring land use/cover change using remote sensing and GIS techniques: a case study of Hawalbagh block, district Almora, Uttarakhand, India. Egypt J Remote Sens Sp Sci 18:77-84. https://doi.org/10.1016/j.ejrs.2015.02.002

Ricaurte LF, Olaya-Rodríguez MH, Cepeda-Valencia J et al (2017) Future impacts of drivers of change on wetland ecosystem services in Colombia. Glob Environ Chang 44:158-169. https://doi. org/10.1016/j.gloenvcha.2017.04.001

Sánchez-Espinosa A, Schröder C (2019) Land use and land cover mapping in wetlands one step closer to the ground: Sentinel-2 versus landsat 8. J Environ Manage 247:484-498. https://doi.org/10. 1016/j.jenvman.2019.06.084

Sewnet A (2016) Land use/cover change at Infraz watershed by using GIS and remote sensing techniques, northwestern Ethiopia. Int J River Basin Manag 14:133-142. https://doi.org/10.1080/15715 124.2015.1095199

Singh A (1989) Review article: digital change detection techniques using remotely-sensed data. Int J Remote Sens 10:989-1003. https://doi.org/10.1080/01431168908903939
Singh KV, Setia R, Sahoo S et al (2015) Evaluation of NDWI and MNDWI for assessment of waterlogging by integrating digital elevation model and groundwater level. Geocarto Int 30:650-661. https://doi.org/10.1080/10106049.2014.965757

Tan KC, Lim HS, MatJafri MZ, Abdullah K (2012) A comparison of radiometric correction techniques in the evaluation of the relationship between LST and NDVI in Landsat imagery. Environ Monit Assess 184:3813-3829. https://doi.org/10.1007/ s10661-011-2226-0

Tatu KS, Anderson JT (2017) An introduction to wetland science and South Asian wetlands. Wetland Science. Springer, New Delhi, pp 3-30

Uddin MJ, Mohiuddin ASM, Hossain ST, Hakim A (2013) Ecoenvironmental changes of wetland resources of Hakaluki haor in Bangladesh using GIS technology. J Biodivers Endangered Species 1:103. https://doi.org/10.4172/2332-2543.1000103

UNEP (2015) Wetlands for our future: act now to prevent, stop, and reverse wetland loss. https://www.unep.org/news-and-stories/ press-release/wetlands-our-future-act-now-prevent-stop-and-rever se-wetland-loss. Accessed 15 April 2021

USGS (2017) What are the band designations for the Landsat satellites? https://www.usgs.gov/faqs/what-are-band-designations-landsatsatellites?qt-news_science_products $=0 \#$ qt-news_science_produ cts. Accessed 7 April 2021

USGS (2018) Using the USGS Landsat level-1 data product. https:// www.usgs.gov/core-science-systems/nli/landsat/using-usgs-lands at-level-1-data-product. Accessed 27 April 2021

$\mathrm{Xu} \mathrm{H}$ (2006) Modification of normalised difference water index (NDWI) to enhance open water features in remotely sensed imagery. Int J Remote Sens 27:3025-3033. https://doi.org/10. $1080 / 01431160600589179$ 